University of Nebraska - Lincoln

DigitalCommons@University of Nebraska - Lincoln

1967

TICKS IN RELATION TO HUMAN DISEASES CAUSED BY

RICKETTSIA SPECIES

Harry Hoogstraal

Follow this and additional works at: https://digitalcommons.unl.edu/usnavyresearch

This Article is brought to you for free and open access by the U.S. Department of Defense at

DigitalCommons@University of Nebraska - Lincoln. It has been accepted for inclusion in U.S. Navy Research by an authorized administrator of DigitalCommons@University of Nebraska - Lincoln. 


\title{
TICKS IN RELATION TO HUMAN DISEASES CAUSED BY RICKETTSIA SPECIES ${ }^{1,2}$
}

\author{
By HaRry HoOgstraAl \\ Department of Medical Zoology, United States Naval Medical Research Unit \\ Number Three, Cairo, Egypt, U.A.R.
}

Rickettsiae (185) are obligate intracellular parasites that multiply by binary fission in the cells of both vertebrate and invertebrate hosts. They are pleomorphic coccobacillary bodies with complex cell walls containing muramic acid, and internal structures composed of ribonucleic and deoxyribonucleic acids. Rickettsiae show independent metabolic activity with amino acids and intermediate carbohydrates as substrates, and are very susceptible to tetracyclines as well as to other antibiotics. They may be considered as fastidious bacteria whose major unique character is their obligate in tracellular life, although there is at least one exception to this. In appearance, they range from coccoid forms $0.3 \mu$ in diameter to long chains of bacillary forms. They are thus intermediate in size between most bacteria and filterable viruses, and form the family Rickettsiaceae Pinkerton. They stain poorly by Gram's method but well by the procedures of Macchiavello, Gimenez, and Giemsa.

Arthropods are frequently infected and are vectors of each rickettsial species that causes illness in humans. Steinhaus (292) has stressed the intimate biological relationships between rickettsiae and arthropods, especially ticks. This suggestion is fully supported by the many phenomena of rickettsial infection, multiplication, long-term maintenance, trans-stadial and transovarial transmission, tick-reservoir tolerance, extensive geographic and ecological distribution, and the variety of infected tick species discussed below.

Human rickettsial diseases may be classified in five major groups on the basis of their clinical features, epidemiological aspects, and immunological characteristics. In the following outline, the Maculatum agent (2B) and those in $2 \mathrm{D}$ have not been associated with human disease.

1. Typhus group

A. Epidemic typhus (louse-borne) (R. prowazeki)

Brill-Zinsser disease (recrudescent typhus) ( $R$. prowazeki)

B. Murine typhus (flea-borne) (R. mooseri)

${ }^{1}$ The survey of the literature pertaining to this review was concluded in March 1966.

${ }^{2}$ From Research Project MR005.09-1402.3, Bureau of Medicine and Surgery, Department of the Navy, Washington, D. C. The opinions and assertions contained herein are the private ones of the author and are not to be construed as official or as reflecting the views of the Department of the Navy or of the naval service at large. The bibliographic compilation for this report was materially assisted through Agreement 352505 between the National Institutes of Health and NAMRU-3. 
2. Spotted fever group (tick-borne except $R$. akari)
A. Rocky Mountain spotted fever ( $R$. rickettsi)
Siberian tick typhus $(R$. siberica)
B. Boutonneuse fever ( $R$. conori)
Maculatum agent ( $R$. parkeri) (?pathogenic)
C. Rickettsialpox (mite-borne) (R. akari)
Queensland tick typhus ( $R$. australis)
D. Eastern Montana agent (R. montana) (?pathogenic)
Western Montana agent (unnamed) (?pathogenic)

3. Scrub typhus (mite-borne) (R. tsutsugamushi)

4. Trench fever (louse-borne) (R. quintana)

5. $Q$ fever (tick and other arthropod-borne; also by contamination) (Coxiella burneti)

The generic name Rickettsia da Rocha Lima is utilized for each rickettsial species pathogenic for man. $R$. quintana differs from other agents of this genus in that it multiplies extracellularly in vitro and in the louse vector (306). The agent of $Q$ fever is placed by some workers in the genus Rickettsia, but by most in the genus Coxiella Philip. Coxiella burneti, the only species in this genus, is also the only agent in this group with a readily filterable phase. It infects ticks, other arthropods, and lower vertebrates in nature but is most commonly transmitted to man through contact with or proximity to infected animals or animal products. Among the numerous fine reviews on $Q$ fever, few present a balanced biological coverage of the epidemiology of this disease or adequately summarize much recent or older work on $C$. burneti infections in nature. It is not possible to do justice to both typical Rickettsia species and to the complex, atypical $C$. burneti within the space limits of the present review.

Until recently Soviet and other writers used Dermacentorxenus Wolbach as a generic name for $R$. siberica, the agent of Siberian tick typhus; others now utilize this name as a subgenus for the Rocky Mountain spotted fever group. Rickettsiae of the genera Cowdria Macchiavello and Erlichia Moshkovsky are pathogenic for lower mammals, especially domesticated animals. Species of the genus Wolbachia Hertig, rickettsialike microorganisms of ticks and insects [see Philip (208)] are not known to be associated with vertebrate illnesses; their role in this respect is under investigation in our laboratories. Philip's $(204,205)$ reviews on the order Rickettsiales summarized the systematic problems, history, and earlier literature of this group.

Important recent background papers on ticks and rickettsiae are by Philip \& Burgdorfer (211) on arthropods as reservoirs of disease agents, Philip (209) on ticks as purveyors of animal ailments, Bertram (29) on rickettsial infections and ticks, Řeháček (249) on viral and rickettsial development in ticks and mites, Krieg (147) on rickettsiae and rickettsioses, and by Bell \& Philip (21) on the human rickettsioses. These classic reviews should be consulted for information on principles of tick and rickettsial relationships. The lifelong studies of Weyer, which he recently summarized (312), are prerequisite to understanding biological associations between rickettsiae and various arthropods. 


\section{TYPHUS GROUP}

\section{EPIDEMic (LOUSE-Borne) Typhus}

The epidemiological pattern of this disease, caused by Rickettsia prowa$z e k i$, has long been considered to be confined to a louse-human-pathogen interrelationship. Thus, frank skepticism first greeted Reiss-Gutfreund's (250252) claims to have obtained antibody reactions and isolation of this agent from domestic mammals and ticks, as well as from a human, in Ethiopia. In 1963, however, Imam \& Labib (119) reported positive complement-fixing reactions against $R$. prowazeki in blood of numerous goats, camels, and donkeys collected in the late fall and early winter in Egypt. In 1962 and 1963, American workers and Reiss-Gutfreund together collected more material in Ethiopia for investigation at the Rocky Mountain Laboratory but the results of these efforts were negative. Later, Reiss-Gutfreund, using ticks (Hyalomma sp.) from Ethiopian cattle, isoltaed strains of epidemic and endemic typhus that were specifically confirmed at the Rocky Mountain Laboratory (218). In Egypt, in the meantime, Imam and associates (120) found a much higher incidence of complement-fixing antibodies against $R$. prowazeki in goats, donkeys, camels, and sheep in a village where human typhus had occurred than in animals from a neighboring village from which no human cases had been reported. Mooser et al. (178) reported on distribution of human typhus in Egypt. El-Zawahry et al. (74) found complement-fixing evidence of recent $R$. prowazeki infection in certain families of desert nomads, and Hoogstraal et al. (114) reported a 31 per cent incidence of typhus group antibodies in spiny mice, Acomys spp., from remote desert valleys near the Red Sea. These mice were heavily infested by larvae and nymphs of the relict tick Hyalomma rhipicephaloides Neumann. An intensive investigation into the epidemiology of epidemic typhus is now being undertaken cooperatively between the Egyptian Government Virus Research Center, Rocky Mountain Laboratory, and U. S. Navy Medical Research Unit No. 3. Philip (210) is studying the possibility of domestic animal and tick infection in South America.

In Ethiopia, Reiss-Gutfreund $(251,252)$ obtained high agglutinin titers against $R$. prowazeki in the blood of approximately 70 per cent of 896 domestic animals by Giroud's micro-agglutination technique and isolated several strains from Amblyomma variegatum (Fabricius). In the earliest study (250), she had also isolated two strains from $A$. variegatum from cattle and four from Hyalomma marginatum rufipes Koch from cattle and camels. Following the inoculation of infected $A$. variegatum and $A$. lepidum Doenitz suspensions into guinea pigs, five strains were recovered from these mammals. Larval and nymphal amblyommas, but not adults, became infected from ingesting blood of infected rabbits and lambs, and in a single instance, Rhipicephalus simus Koch also did so. The Amblyomma ticks remained negative following feeding on infected adult sheep or heifers. Infected mammals did not display clinical symptoms but lambs continued to act as rickettsial carriers for several weeks after inoculation. 
Thus, it appears that in certain parts of Africa, epidemic typhus may be a zoonosis, with a mammal-tick-mammal cycle and a human-louse-human cycle. Possible interactions between these cycles remain to be determined. It should be pointed out, also, that nowhere except in Ethiopia have strains of $R$. prowazeki been isolated either from animal tissues or ticks in spite of extensive and intensive efforts to do so.

Payzin \& Akan (202) call attention to the fact that in the housing conditions of eastern and central Turkey where there is a high incidence of epidemic typhus in early childhood, rats, fleas, ticks, and domestic animals are all intimately associated with human beings. Under tropical conditions, as exemplified by those in central Africa, a variety of rickettsial agents may be present and account for many human fevers of unknown origin (121).

$R$. prowazeki multiplies in Ornithodoros moubata (Murray) (310) and also reproduces and becomes widely disseminated, particularly following a blood meal, in the body of $O$. papillipes Birula after parenteral inoculation (127). Experimental infection of Dermacentor marginatus (Sulzer) and D. pictus (Hermann) is said to kill these ticks, as it does lice (231). Kordová \& Řeháček (135-138, 249) suggest, as a result of studies on experimental infections of $R$. prowazeki and of Coxiella burneti in ticks (D. marginatus, Ixodes ricinus, and Hyalomma asiaticum subsp.), that the variety of morphological changes in the rickettsiae and in their host cells is associated with developmental phases of these organisms within tick cells. In a study (6) of $C$. burneti in the yolk sac of the developing chick embryo, similar "atypical" forms were not identified although the Czech workers have reported their presence in similar circumstances.

\section{SPOTTED FEVER GROUP}

Species relationships in the spotted fever group have been clarified on the basis of data obtained by complement fixation tests with washed rickettsial suspensions and from cross-immunity tests in guinea pigs inoculated with living rickettsiae or formalin-killed vaccines (155). Other tools are the mouse toxin-neutralization test $(22,23)$ and the complement-fixation test using species-specific complement-fixing antibodies produced in mice (220). Utilizing data obtained from each technique, Lackman et al. (157) have recently reclassified spotted fever group agents into four subgroups.

\section{Rocky Mountain Spotted Fever (Subgroup A)}

Current public health problems concerning Rocky Mountain spotted fever are expressed by Dr. David B. Lackman (abstract of personal communication, 1966) of the Rocky Mountain Laboratory as follows: These problems can be grouped under recognition, vaccination, and control. Part of the problem of recognition is the attitude that "it can't happen here." Fatal cases are cited in which the attending physicians were convinced of the correct diagnosis only following isolation of $R$. rickettsi. Ticks were abundant in the arcas in which these cases occurred. The watchword should be: 
"Whenever you have ixodid ticks biting man there is the possibility of Rocky Mountain spotted fever." A general vaccination program is hardly justified in most areas owing to the peculiar distribution of cases and effectiveness of antibiotic therapy. For control personal tick hygiene remains the key. Environmental control of ticks by pesticides or other measures is practical only in limited areas.

Rocky Mountain spotted fever, also known in Latin America as Mexican spotted fever, Tobia fever, or São Paulo fever, caused by $R$. rickettsi (Wolbach), is epidemiologically (206) and serologically (157) closely related to Siberian tick typhus, caused by $R$. siberica. The classic epidemiological and laboratory studies on this disease during the first half of the twentieth century established research patterns and methods that have been applied to numerous tick and other vector-borne disease situations throughout the world. Among the many reviews on the inspiring pioneer works of $\mathrm{H}$. T. Ricketts, R. R. Parker, R. A. Cooley, W. V. King, S. B. Wolbach, H. R. Cox, $\mathrm{R}$. R. Spencer, and many others, the reader is referred to the extensive summary of Parker \& Oliphant (192) and to the shorter, more recent one of Eklund, Stoenner \& Kohls (71). Woodward \& Jackson (319) described clinical and therapeutic advances in this disease. Price's (243) popular, lively account of the history of the fight against spotted fever in the Rockies included numerous anecdotes and literature references not generally embodied in strictly scientific reports. R. Spencer (289), who, together with R. R. Parker, made important pioneer characterizations of $R$. rickettsi and its tick relationships, has also written a short, delightful account of the early history of spotted fever. In the present paper, we shall deal only with recent developments and succinctly summarize the associations of ticks with this disease.

Notable recent advances in the knowledge and handling of spotted fever are (a) application of quantitative methods to recognize differences in rickettsial strain virulence; $(b)$ therapy by tetracyclines, chloramphenicol, and other antibiotic drugs; $(c)$ reduction in incidence and severity of the disease in western North America owing to these drugs and possibly also to changes in environmental factors and consequent epidemiological modifications; $(d)$ intensive epidemiological studies of foci in the eastern United States; (e) demonstration of the identity of rickettsial strains from South, Central, and North America; $(f)$ application of modern laboratory techniques to microbiological studies of the agent; and $(\mathrm{g})$ renewed interest in arthropodvertebrate-pathogen interrelationships.

Variation in virulence of $R$. rickettsi raised many questions for early investigators. Price (244-246) therefore made a comprehensive attempt to establish a quantitative basis for differences and changes in virulence, nature of the reactivation phenomenon, and associated enzyme changes. He successfully demonstrated that differences in strain virulence are not attributable to numbers of viable organisms injected, to qualitative or quantitative differences in measurable enzyme activity, to multiplication rate, or to quantitative growth differences in most tissues and organs of the host. Virulent and 
avirulent strains did not appear to differ antigenically. Virulent strains characteristically were found in greater concentrations than less virulent strains in brain, heart, and blood. Reactivation of $R$. rickettsi appeared to be related to its ability to grow in the mammalian host. Avirulent phase organisms did not grow in guinea pigs; reactivated rickettsiae did.

Major studies on pathology, clinical aspects, diagnosis, and therapy of Rocky Mountain spotted fever following the use of antibiotics in 1948 are: Chang et al. (55), Fuller (81), Harrell (101-103), Ley \& Smadel (161), Lillie (162), Smadel and colleague (275-277, 279), Snyder (282), Wolbach (315), Woodward et al. (317-321), and Workman et al. (322).

Following the advent of antibiotics, the mortality rate in spotted fever cases has been greatly reduced. From 194:5 through 1954, 2239 cases were reported in southcastern United States and 2278 cases elsewhere in the country (54). Since 1959, the number has increased slightly over the 199 recorded for that year. Incidence statistics, however, are no longer reliable owing to the almost universally prompt treatment of fevers by antibiotics in the United States. Mild cases, of ten without rash, are probably not properly diagnosed or reported (275) and actual incidence of the disease is undoubtedly considerably higher than is recognized (11). The fatality rate in Latin America remains high (71). Although discounted by some authorities, the vastly changed environmental conditions of the modern western United States, effects of rodent and tick control programs, behavioral differences between contemporary and pioneer human beings in the field, sanitary habits, vaccination projects, greater attention. and sentitivity to noxious arthropods, and similar phenomena of twentieth century America should also be considered as possible factors in the lower incidence of Rocky Mountain spotted fever in the West.

The presence of Rocky Mountain spotted fever in eastern United States was first recognized in 1931 (17). The virulence of eastern and western strains is similar $(101,303,304)$. In the East, where the chief vector, Dermacentor variabilis (Say), often parasitizes domestic dogs, women and children account for at least half of the reported cases of the disease. In the West, adult male hunters, foresters, stockmen, miners, and outdoor workers who are bitten by $D$. andersoni Stiles and by other tick parasites of wild animals, are the most numerous victims. In Virginia (286a, 288), with its increasing human population, the suburbs have become high risk areas for spotted fever (11) because of the encroachment of residential areasinto abandoned fields and woodlands and the considerable rodent and tick activity found in these situations. In this state, the attack rate of 6.6 per 100,000 persons (275) is the highest of any in the East. During the past few years, an extensive study of tick vectors and spotted fever epidemiology near Montpelier, Virginia, has been undertaken collaboratively by Sonenshine et al. (287). A brilliant series of reports is now in preparation or in press by these authors. Among the titles are: "The ecology of ticks transmitting Rocky Mountain spotted fever in a study area in Virginia" (Sonenshine, Atwood, and Lamb), "Activity of the American 
dog tick in relation to solar energy changes" (Atwood and Sonenshine), and "Some host-parasite relationships involving the feeding of subadult Dermaacentor variabilis on small mammals" (Sonenshine and Atwood). Cases of this disease are reported each year in Pennsylvania (281) and in Georgia (170).

Several new techniques for microbiological research are being applied to investigations on interrelationships between ticks, vertebrate hosts, and $R$. rickettsi. A frozen section method for rapid sectioning of arthropods, in which specimens are quick-frozen in gelatin and rapidly sectioned in a freezing cabinet at $-15^{\circ} \mathrm{C}$, allows excellent preservation of internal structures of nymphal and adult argasid and ixodid ticks (301). This technique is useful for histological studies on the relationship of organ systems, localization of conventionally stained parasites and pathogens, and fluorescent antibody studies on development and behaviour of disease agen ts in arthropods.

Earlier workers were unable to distinguish between $R$. rickettsi and $W o l$ bachia organisms in smears of ticks. The fluorescent antibody technique is a rapid and reliable diagnositc tool for distinguishing $R$. rickettsi in gut tissue smears of experimentally infected Dermacentor ticks $(41,43,267)$.

The fluorescent antibody technique also aids attempts to settle the moot question of transovarial transmission of $R$. rickettsi by ticks. Early workers had reported that 12,30 , or 50 per cent of infected $D$. anderson $i$ females transmitted the rickettsiae transovarially and that not all eggs in each infected batch contain this agent. Using an eastern, low virulence strain in $D$. variabilis, Price (246) found that 30 to 40 per cent of infected females pass the agent to their offspring and that fewer than half of the eggs and $F_{1}$ larvae, nymphs, and adults yielded the organism. Utilization of the fluorescent antibody technique in $D$. andersoni (42) showed 100 per cent transmission of a highly virulent strain via eggs to $F_{1}$ females and to their progeny. Fluorescent antibody-stained sections of ovarian tissues from infected females revealed the presence of rickettsiae in the cytoplasm, but never in the nuclei, of every developing egg. During the study, rickettsial infectivity remained unchanged, as indicated by inoculation of tick eggs in to chick embryos and by feeding ticks on guinea pigs. It is anomalous, however, that the highest index of D. andersoni infection ever found in nature was 13.5 per cent (Bitter Root Valley of Montana) (206). The question therefore arises whether laboratoryinduced transovarial efficiency accurately reflects what occurs in nature or whether certain ecological, dosage, or virulence factors are responsible for eliminating rickettsial infection in wild ticks. Possibly the dosage of agents obtained by many ticks during feeding on an infected host in nature is not always sufficient to stimulate transovarial transmission (42).

In the United States, antibodies against $R$. ricketts $i$ have been demonstrated in blood sera of 18 species of birds and 31 species of mammals ( 5 leporids, 18 rodents, 1 insectivore, 5 carnivores, 1 marsupial, 1 artiodactyl), all common hosts of ticks that transmit this agent. Wild animals apparently experience a very transitory infection with this parasite, thus early attempts 
to recover $R$. rickettsi from these sources had always failed. Gould \& Meisse (94) recently isolated this rickettsia for the first time in a wild animal, from a meadow vole (Microtus pennsylvanicus) in Virginia. In the Virginia ecological study mentioned above, strains of $R$. ricketts $i$ have been recovered from the cottontail rabbit (268), meadow vole, white-footed mouse, pine mouse, cotton rat, and opossum (286). The first such isolations west of the Mississippi River, all from young animals that had not yet developed the rapid antibody rise characteristic of this infection, were those of Burgdorfer et al. (44) on the west side of the Bitter Root Valley, from a golden mantled ground squirrel (Citellus lateralis tescorum), chipmunks (Eutamias amoenus), and a snowshoe hare (Lepis americanus). In this locality, in spite of heavy infestation by immature $D$. andersoni and close association with seropositive ground squirrels and chipmunks, none of 17 woodrats (Neotoma c. cinera) showed evidence of infection. Earlier, Ricketts had found that woodrats are as susceptible to experimental infection as any of the host mammals mentioned above.

The epidemiology of spotted fever is intimately associated with several species of ticks and with their wide variety of hosts. The incidence of the disease in humans, who do not serve as reservoirs, depends largely on the behavior of the vectors, their distribution and ecology, and either on the tick's encroachment into the human domain (suburbia) or on man's penetration of the tick's wild domain. The complex interrelationships of population densities and annual cycles of abundance of ticks and of their hosts are also important factors in respect to human disease incidence. The undiminished virulence of $R$. rickettsi strains, passed trans-stadially and transovarially through several generations of ticks, serves to maintain an infected focus through inclement years.

Owing to the short duration of rickettsemia in susceptible animals, an important factor in the maintenance of spotted fever is the simultaneous feeding of infected and noninfected ticks on immature animals (246). Infection of female $D$. andersoni ova by rickettsia-bearing male sperm during copulation (214) is a potential factor that requires further investigation in maintenance of cycles in nature. Male ticks, which remain on the host for long periods and of ten mate with several females, may thus infect the progeny of more than a single female.

R. rickettsi is excreted with the various defecation materials of female $D$. andersoni during and following engorgement. Contaminated feces, however, do not appear to be an important factor in transmitting the agent to other hosts, including humans; they thus differ in this respect from tick feces containing the agents of tularemia and $Q$ fever. Fleas and mosquitoes appear not to be reservoirs or vectors of $R$. rickettsi (206). Although bed bugs have been reported to be vectors in Brazil (166), Weyer's (311) finding of a short survival duration of the agent in artifically infected bugs tends to discount this claim.

According to Parker \& Oliphant (192), the spotted fever of Canada, United States, Mexico, Colombia, and Brazil "appear beyond a question to 
represent a single disease entity as indicated by cross immunity in laboratory animals, clinical evidence, and the fact that vaccine prepared from United States strains protects equally well against strains resident in other countries."

The incidence and wide distribution of the disease in the United States have been frequently reported and reviewed. In Canada, Rocky Mountain spotted fever occurs in British Columbia, Alberta, Saskatchewan, and possibly in Manitoba. It is most virulent in southern Alberta, where five fatalities occurred among nine known and four suspected cases. About 2 per cent of $D$. andersoni taken in southern Alberta were infected by $R$. rickettsi (34). Haemaphysalis leporispalustris (Packard) and Rhipicephalus sanguineus (Latreille) are considered to be potential vectors in Canada. Strains of the agent recovered from British Columbia were avirulent $(98,99)$. Antibodies to $R$. rickettsi were demonstrated in a number of snowshoe hares and in a groundhog (Marmota monax) in Ontario (182).

In Mexico, where the first cases were reported in 1943 (45), the disease has been recorded from many states. $R$. sanguineus is frequently infected as well as Amblyomma cajennense (Fabricius) in Veracruz $(46-49,73,187)$. A vaccine was easily and cheaply prepared from $R$. sanguineus (186). Domestic animals on certain Mexican farms where human cases occurred had higher complement-fixing antibodies than those from other farms; in these localities $R$. sanguineus, Ornithodoros nicollei Mooser, and Otobius lagophilus Cooley and Kohls were all infected by $R$. rickettsi (271-274).

In Panama, a highly virulent strain of $R$. rickettsi was isolated from the blood of a fatal spotted fever case in 1950 (260). Adult $A$. cajennense removed from a horse in the vicinity of the patient's farm also yielded the agent (259).

In Colombia, a 1934-1936 outbreak in the Tobia River Valley took the lives of 62 of 65 patients (198). Subsequently, naturally infected A. cajennense and Dermacentor (Anocentor) nitens Neumann were found in this area and the latter species was shown to be able to transmit the rickettsia under experimental conditions (197). All residents of Tobia Valley, and their dogs, horses, and mules, but not cattle, were heavily infested by various potential vectors. Among these were Ornithodoros rudis Karsch ( $=0$. venezuelensis Brumpt) (in beds), A. cajennense (from human clothes, horses, and mules), D. nitens (from horses and mules), and $R$. sanguineus (from dogs). A variety of small native mammals inhabit this temperate valley (700 to 1200 meters in altitude), which is devoted to cultivation of sugar cane, corn, yucca, and bananas.

In Brazil, "S̃̃o Paulo typhus" was encountered in 1928. Cases occurred among the large numbers of recent Russian and Slovak immigrants and were first considered to be European typhus. The 68.5 per cent incidence of disease in women and children was attributed to the fact that while men went to the city to work, other members of the family remained at home in the rural or semirural zone surrounding Sào Paulo. The vegetation here was intensely tick-infested and wild guinea pigs were common in the undergrowth (302). The disease was also found in Minas Geraes in 1933, together with circumstantial evidence that it had occurred for many years previously. The chief 
vector is $A$. cajennense; experimentally, this species and $A$. striatum Koch, $A$. brasiliense Aragāo, and $Q$. sanguineus have been shown to transmit Brazilian strains of $R$. rickettsi. In some instances, transovarial transmission has also been demonstrated. Ornithodoros rostratus Aragāo transmitted the agent by feeding for 13, but not 28 days, following inoculation. O. turicata (Dugés) (38, 40) retains the rickettsia in its body for 28 months but is unable to transmit it during biting. Boophilus microplus (Canestrini) is considered to be a potential vector. Dogs are said to be common reservoirs of this rickettsia in Brazil and their ticks ( $A$. cajennense and $A$. striatum) are naturally infected. $A$. cajennense from a fatal human case and from a farm where two fatal cases occurred also yielded strains of $R$. rickeitsi. Opossums (Didelphis spp.), rabbits (Silvilagus minensis), and wild guinea pigs (Cavia aperea) are also said to be reservoirs. The literature concerning this disease in Brazil was reviewed by Dias \& Vianna Martins (67).

The statement (10) that geographical areas infected with tick paralysis do not have Rocky Mountain spotted fever is erroneous (133).

An excellent, brief training manual by Pratt \& Littig (241) includes essential details for recognition of North American tick vectors and their biology and control. For the identification of Dermacentor adults, nymphs, and larvae in western United States, see Brinton, Beck \& Allred (36). The Dermacentor ticks of the United States were monographed by Cooley (61). The intimate relationships between Dermacentor ticks and rabbits and hares in many parts of the world is a significant factor in the transmission cycle of pathogens causing several human diseases (see pages 393 and 401).

Dermacentor parumapertus Neumann ticks naturally infected by a strain of $R$. rickettsi that was only slightly pathogenic for guinea pigs and that showed certain immunological differences from typical strains, were reported by Philip \& Hughes (212). Experimentally, however, this species has been shown to be as able as $D$. andersoni to transmit virulent strains. $D$. parumapertus feeds almost exclusively on rabbits and hares in most areas of southwestern United States $(5,18,19,82,122)$. Immature stages may infest other small mammals (36). Adults are sometimes found on cattle (294), deer, and coyote (61).

Dermacentor andersoni (Stiles) ranges through 14 states from western Nebraska and the Black Hills of South Dakota to the eastern slopes of the Cascades and from northern Arizona and New Mexico into British Columbia and Manitoba. It is especially common in cutover mountainous areas and in sagebush thickets along streams. Larvae and nymphs are indiscriminate parasites; they feed on practically every rodent, small carnivore, hare, rabbit, or porcupine within their reach. Adults parasitize hares and porcupines but more of ten larger wild and domestic mammals, and eagerly bite man. Nymphs sometimes infest children. The life cycle is usually completed in two years. Both nymphs and adults overwinter, and activity is confined to spring and early summer $(32,61)$. Many epidemiological studies of spotted 
fever in the West include information on the biology of this tick and on its relation to this disease.

D. variabilis Say occurs east of the Rocky Mountains, in certain localities of California, and also in Mexico (111) and Canada (98); it is most abundant along the east coast and in parts of Wisconsin, Minnesota, Iowa, and Texas. Larvae and nymphs feed chiefly on small rodents. Adults parasitize larger mammals especially dogs, and also man $(32,61)$. In a major study of the biology and control of D. variabilis in Massachusetts, Smith, Cole \& Gouck (280) stressed the importance of meadow mice (Microtus pennsylvanicus) and of domestic dogs as hosts and the proximity of active ticks to paths and roadsides. Adults hibernate, become active in April, reach maximum numbers by June or July, and cease activity in August or September. Some nymphs overwinter, others emerge from the larval stage in summer; their period of activity is somewhat longer than that of adults. Larvae either hibernate or hatch in summer and can be found from March to September. Peak densities of larvae vary through these months owing to hatching of egg masses at different times. The incubation period ranges from 36 to 57 days. Maximum observed longevity was 540 days for larvae, 584 days for nymphs, and more than two years for adults. Control of ticks on domestic animals, eradication of meadow mice, and burning grass cover (especially in April) are recommended. Excellent control methods for populous areas, by the application of chemical sprays, were also developed by Collins \& $\operatorname{Nardy}(59,60)$.

D. albipictus (Packard), a wintertime tick of large wild and domestic animals in Canada (98), northern and western United States (61), and mountainous areas of Mexico (111), of ten but not always acts as a one-host parasite (118). This species was implicated in the Olympia Peninsula of Washington where a man, who was bitten by a tick that detached from a recently killed elk, became ill with spotted fever (213). D. (Anocenter) nitens Neumann, the tropical horse tick, has recently been found to be well established in southern Florida. It occurs elsewhere in most Caribbean countries, Mexico, Central America, part of South America, and several counties of Texas. $D$. nitens is a one-host tick infesting ears of horses and other domestic animals, and of deer and man in warm, humid areas with mild winters (239).

A mblyomma americanum (Linnaeus) nymphs taken from vegetation near the home of an Oklahoma child who recovered from spotted fever in 1942, yielded strains of the agent. Dogs of the family were heavily infested by nymphs and the mother frequently found nymphs on herself, her children, and a two-month old infant. Previous data from other cases in southern United States appear also to have been associated with A. americanum (193). All stages of $A$. americanum, the "lone star tick," readily attack man; the severe itching that results may persist for a long time. Although a three-host tick, each stage of $A$. americanum infests the same extensive variety of domestic and wild mammals, and occasionally birds. This vector of many pathogens causing human and animal diseases occurs in the south-central and 
southeastern states and is especially abundant near the Gulf of Mexico and in the Ozark Mountains. The range extends into Mexico (111). In the United States, adults feed from February to midsummer, larvae appear in late spring, and immature stages are active till late fall. A. americanum is more difficult to remove than most other American ticks when attached to its host (129). The tick can usually be detached intact by inserting the tip of a scalpel or needle under the exceptionally long mouthparts and applying gentle, slow, gradually increasing traction. Application of 0.6 per cent pyrethrins in methyl benzoate or of camphorated phenol to the skin about 20 minutes before attempted removal of the tick reduces the pull required to detach $A$. americanum (128). Frequent, careful inspection of the body when in potentially dangerous areas should reduce the danger of infection. Unfed ticks seldom feed immediately on a host and they rarely transmit rickettsiae until several hours following initial attachment. Persons who handle tick-infested animals should be especially alert. According to many other observers and in our own field experience, many tick species often leave a dead host, eagerly seek a live one, and avidly attack it. Ticks being removed from an animal by hand of ten rapidly attach to a human if it is possible for them to do so.

A mblyomma cajennense (Fabricius), a troublesome pest of man and domestic animals, is of ten abundant and active the year around in the American tropics from southern Texas to Argentina $(9,69,80,158)$. All stages, but especially larvae and nymphs, aggressively attack man and are difficult to remove and to find among clothing. Wild birds and mammals are also hosts $(32,63)$. An infestation in a Trinidad coconut plantation, which reached the proportions of eight ticks per square foot of ground, caused so much distress that laborers refused to work in the field (2). Much of the taxonomic and biological literature concerning $A$. cajennense has been reviewed by Hoff mann (111) and this species has been mentioned by all writers on spotted fever in Central and South America. ${ }^{3}$

Haemaphysalis leporispalustris (Packard), collected in eastern United States, was found to be naturally infected by $R$. rickettsi of consistent low virulence in 1951 (195). Earlier, Parker (189), in Montana, had demonstrated that his characteristic parasite of rabbits and hares can transmit the rickettsia from host to host by biting, that infected individuals occur in nature, and that transovarial transmission also occurs. The geographic range of this species (132) is from near Circle, Alaska (217), through Canada (98), United States (32, 62), Mexico (111), and Central and South America to Argentina.

${ }^{3}$ The transmission tests performed with ticks attributed to $A$. cajennense from Oklahoma [Parker, R. R., Philip, C. B., and Jellison, W. L. Rocky Mountain spotted fever. Potentialities of tick transmission in relation to geographical occurrence in the United States. Am. J. Trop. Med., 13, 341-79 (1933)] were actually done with a recently recognized species, $A$. imitator [Kohls, G. M. Amblyomma imitator, a new species of tick from Texas and Mexico and remarks on the synonymy of A.cajennense (Fabricius). J. Parasitol., 44, 430-33 (1958). 
Kohls (131) stressed the probable importance of this tick and its rabbit and hare hosts in maintaining the spotted fever cycle in nature. Although $H$. leporispalustris seldom infests man, other ticks that do so also feed on the same leporid hosts. Larvae and nymphs usually parasitize rabbits, hares, or ground-feeding birds. Tremendous numbers sometimes infest a single host. In northern United States, each stage is active from early spring to early fall; in the South these ticks are found during most or all of the year. Thelife cycle usually requires a single year. In the ecological classifications of parasites for epidemiological purposes proposed by Audy (12) and by Pavlovsky in numerous papers, the immature stages of $H$. leporispalustris behave as fielddwelling parasites but adults are nidicoles. The implications of these patterns in relation to host finding and research problems have been discussed by Camin $(50,51)$ and George $(89,90)$. This tick species has recently been the subject of several notable field and laboratory studies $(70,97,123,175-177$, 239, 290, 316).

Rhipicephalus sanguineus was reviewed by Hoogstraal (112).

Ornithodoros (Pavlovskyella) nicollei Mooser, found in peasant homes and caves, is widely distributed in Mexico and nearly islands, parasitizes many kinds of reptiles and mammals, including man, and is sometimes imported into zoos in the United States $(111,134) . O$. (P.) rostratus Aragão, a parasite of man and dogs in human habitations in northern Argentina, Brazil, Paraguay, and Bolivia, also feeds on peccaries and livestock $(9,33)$. Its reported occurrence in French Guinea is doubtful (80). O. rudis Karsch is a common parasite of man in houses in Panama and parts of South America (134).

Otobius lagophilus Cooley and Kohls, a charactcristic parasite of lagomorphs in arid and semiarid areas of western Canada, United States, and Mexico, acts as a one-host tick during its larval stage and two nymphal instars; adults have rudimentary mouthparts and do not feed $(16,117)$. Naturally infected specimens were reported from Coahuila, Mexico (273) and this species was implicated in spotted fever epidemiology in Nevada (216). For an excellent study of the biology, anatomy, and morphology of $O$. lagophilus see Herrin \& Beck (110).

\section{Siberian Tick Typhus (Subgroup A)}

Siberian tick typhus was brought to medical attention and described under numerous names in the 1930's when a variety of virgin steppe lands was penetrated for agricultural and industrial purposes. In 1937-1938, these alarums led to the first of numerous expeditions of biomedical investigators into the Kransoyrarsk region and later to other foci. Utilizing the epidemiological experience and technological skills reported for the closely related Rocky Mountain spotted fever, as well as the considerable organizational ability and leadership of the late Academician, E. N. Pavlovsky, soviet scientists soon established the cpidemiological pattern of the Asiatic disease. The insight gained from this effort is credited with furnishing Pavlovsky 
with much of the inspiration for developing his well-known outline of principles, or theory, of natural focality of disease (232). Once the clinical and epidemiological features of Siberian tick typhus had been delineated, it was found also to occur among established native populations outside of virgin lands. Foci are now known from islands in the Sea of Japan and through the Pacific Far East (Primorsk, or Maritime Territory), and many areas of northern and southern Siberia. to the Mongolian, Kazakh, Kirgiz, and Armenian Republics. Numerous yet unrecognized foci are presumed to exist throughout Asiatic Russia and the Soviet republics of central Asia. Thus, the name Asian tick typhus applied by some specialists is even more appropriate than Siberian tick typhus.

Correct clinical diagnosis apparently remains an important problem in some areas. The two-week illness with fever, malaise, headache, conjunctival injection, and extensive rash beginning on the third to fifth day of pyrexia, is clinically much like moderately or mildly severe Rocky Mountain spotted fever. Prognosis is usually good. Therapeutics are similar to those used for Rocky Mountain spotted fever $(163,232)$.

The history of research on Rickettsia (or Dermacentroxenus) siberica, the agent of Siberian tick typhus, has beerl reviewed in detail $(163,325) . R$. rickettsi and $R$. siberica have been shown by a variety of microbiological tests to be closely related $(150,325)$ and Lackman et al. (157) classified the two in the same subgroup.

Strains of $R$. siberica have been isolated from at least 18 kinds of mammal hosts of vector ticks. Among these are the long-tailed Siberian ground squirrel, or suslik (Citellus undulatus) in Krasnoyarsk $(140,148)$ and Khakass (142) areas; red-cheeked suslik (Citellus major erythrogenys) in Novosibirsk area (266) and (C. major subsp.) in Tumen area (307); chipmunk (Eutamais sibericus) in Khabarovsk area (263); common hamster (Cricetus cricetus) in Novosibirsk area (266); grey hamster (Cricetulus migratorius) in Armenia (145, 146); Far Eastern striped hamster (Cricetulus barabensis) in Khabarovsk area (263); Norway rat (Rattus norvegicus caracao) in Khabarovsk are (263) and (R. n. norvegicus) in Krasnoyarsk area (148); domestic mouse (Mus musculus) in Khakass area (142); steppe lemming (Lagurus lagurus) in Khakass area (141); striped field mouse (Apodemus agrarius) in Khabarovsk (263) and Novosibirsk (266) areas; large-toothed redbacked vole (Clethrionomys rufocanus) in Primorsk area (160); northern redbacked vole (Clethrionomys rutilus) in Tumen area (307); narrow-skulled vole (Microtus gregalis) in Krasnoyarsk (148, 234), Khakass (141), and Novosibirsk (266) areas; reed vole (Microtus fortis michnoi) in Khabarovsk (263) and Primorsk (160) areas and on an island in the Sea of Japan (285); red-tailed jird (Meriones erythrourus) in south-western Kirgizia (247); and European hare (Lepus europaeus) in Khakass area (142). Ticks removed from domestic cattle, sheep, and dogs have been reported to be infected.

Most authors of reported $R$. siberica isolations from mammals also recorded, in the same or in other papers, strains of the rickettsia from associ- 
ated ticks. Little mention of the length of rickettsemia of $R$. siberica in rodent reservoirs is found in Soviet papers available to us. One should recall the very brief period in which the agent of Rocky Mountain spotted fever circulates in mammals, and the troubles that this phenomenon caused early American investigators. Although some workers have noted that $R$. siberica was recovered from young animals, others have not stated the age of the host or else have obtained this agent from adult rodents. For instance, strains in the Khakass region were isolated in early spring, before activity by larval Dermacentor nuttalli commenced, from susliks, lemmings, and voles that were just emerging from hibernation (144). Kulagin (quoted by Lyskotsev), on the other hand, reported no isolation from rodents during the spring and Lyskotsev (163) states that rodents are infected only when they are being parasitized by infected ticks. Thus, the rickettsemia patterns of $R$. rickettsi and of $R$. siberica in rodents may or may not be similar. The very short life span of many rodents, of ten no longer than eight or nine months, makes it unlikely that they serve as long-term reservoirs. Although serological evidence of infection of domestic cattle, calves, sheep, and horses has been obtained, attempted rickettsial isolation from these animals has been unsuccessful (307).

Birds parasitized by larvae of Haemaphysalis concinna appear to play a secondary role as reservoirs of $R$. siberica in forested areas where this tick occurs. In northwestern Primorsk (Far East), Somov \& Soldatov (284) isolated the rickettsia from a group of four thick-billed shrikes (Lanius tigrinus), and also from larval and nymphal $H$. concinna from a masked bunting ( $E m$ beriza spodocephala). In this study, 366 birds representing 35 species were investigated. Evidence of infection was obtained in the masked bunting, Siberian grey-headed bunting ( $E$. fucata), chestnut bunting ( $E$. rutila), yellowthroated bunting ( $E$. elegans), yellow-breasted bunting ( $E$. aureola), bullheaded shrike (Lanius bucelaphus), tree sparrow (Passer montanus), and Siberian flycatcher (Muscicapa siberica). The unusual occurrence of larvae and nymphs of Dermacentor nuttalli on birds was also noted. While 32 specimens of this tick were found on the 366 birds that were studied, only seven were on the bird species listed above. In contrast, 138 larvae and nymphs of $H$. concinna were removed from the 366 birds but the host list of this tick species included most of the bird species mentioned here.

Tick typhus in Asiatic USSR is usually associated with different Siberian dry steppe landscapes receiving less than $300 \mathrm{~mm}$ of rain annually (232), though the area of distribution may extend a certain distance into other ecological zones bordering steppes (203). Steppe lands of Siberia have been extensively described and illustrated by Suslov (295); these areas are often close to mountain ranges and foothills and may extend up dry slopes into the alpine zone.

Where Dermacentor silvarum infests adjacent taiga and shrub-wormwood steppes, tick typhus and spring-summer encephalitis occur together. In the Far East, where Haemaphysalis concinna is the chief vector in shrub and fern 
marshes with grassy tussocks adjoining taiga forests, tick typhus may occur during summer and encephalitis during spring. Foci of tick typhus (and $Q$ fever) in southwestern Kirgizia, where the southern steppes give way to a foothill semidesert zone, are associated with red-tailed jirds along dry waterways overgrown with shrubs and along irrigation canals. Here Hyalomma asiaticum parasitizing jirds in their burrows are infected by $R$. siberica (247).

Results of serological surveys of the human population and of domestic and wild mammals, and recovery of rickettsial and viral strains from ticks in western Siberia, have led Netsky \& Shaiman (181) to conclude that all ecological zones in this region harbor foci of tick typhus, $Q$ fever, and spring-summer encephalitis; in some areas, Omsk hemorrhagic fever also occurs. $Q$ fever predominates among domestic animals; the other foci are associated with wild animals. In the Far East, on the other hand, secondary scrub forests that replace cutover virgin taiga forests become foci of thick typhus while foci of spring-summer encephalitis disappear. In the latter region, forest fires, farm and garden activities, and other human causes of reduction in rodent population densities may lead to decreased incidence of tick typhus (242).

Nine tick species have been reported to be reservoirs and vectors of Rickettsia siberica. Four are in the genus Dermacentor and three in Haemaphysalis. The others are Rhipicephalus sanguineus from sheep and dogs in Armenia (146), and Hyalomma asiaticum subsp. from jirds in Kirgizia (see paragraph above).

Other arthropod parasites of rodents have also yielded strains of $R$. siberica but their role in the epidemiological chain has not been precisely demonstrated. Among these are mites of the genera Hirstonyssus, Haemolaelaps, Nothrolaspis, Schoengastia, and gamasid mites $(266,285)$ and fleas (Neopsylla setosa and Ctenophthalmus arvalis) (163).

Dermacentor ticks are an important component of the Eurasian parasite fauna. Several common, widely distributed species occur in steppe lands and mixed or second growth forests but seldorn in taiga forest. Adults feed on medium and large size wild and domestic mammals. Larvae and nymphs infest rodents, hedgehogs, hares, and smaller carnivores. Birdsare rarely utilized as hosts. Each developmental stage may overwinter on the ground. Some males of each species remain attached to the host in winter but do not feed during this time $(4,20)$. Adult host-questing and feeding commences with the early signs of spring, or shortly afterwards, and usually continues till summer with a lesser wave of activity in fall. Immature stages in more protected niches are most of ten active from spring through fall. Under favorable conditions, the life cycle is completed within a year, otherwise one or more summer or winterdiapauses, or both, occur $(25-28,66,248,323,324)$ and the life cycle may extend over two to four years. Among other environmental factors, diapause thus can affect importantly the length of time during which rickettsiae may be harbored by individual ticks. Olsufjev (184), in discussing relationships between tularemia and ticks, suggests the coevolution of hares (Lepus spp.) and Dermacentor ticks and emphasizes their close host-parasite 
association in northern Eurasia and America. ${ }^{4}$ As mentioned in the following discussion of boutonneuse fever, Rickettsia conori, rabbits, and Dermacentor ticks are so intimately associated in France that the incidence of boutonneuse fever dropped considerably in that country following the dieoff of rabbits during the recent European myxomatosis epizootic $(77,91)$.

Much early literature concerning Dermacentor ticks in the USSR has been summarized by Anastos (7). The more serious reader is referred to the papers of Lyskovtsev (163), in which many important data from biological, epidemiological, and ecology studies published only as obscure graduate dissertations or conference reports are reviewed in detail. Reznik $(253,254)$ described Eurasian Dermacentor larvae and nymphs. Views of the Russian school on taxonomy and systematics are expressed by Pomerantzev (236). Philip (207) and Kohls (133) noted some of many pitfalls in a review of Dermacentor (10).

The agent of Siberian tick typhus survives for at least five years, or through the fourth generation, in both experimentally and naturally infected $D$. marginatus. Trans-stadial and transovarial transmission have been demonstrated (232) for each Dermacentor and Haemaphysalis species mentioned here (except $H$. japonica douglasi). Strains of $R$. siberica vary in virulence. For instance, "highly virulent" strains were isolated from $D$. nuttalli and $D$. silvarum in different parts of Buryat, ASSR (143). Strains isolated from ticks (D. silvarum and $H$. concinna) and rodents (Microtus fortis subsp. and Clethrionomys rufocanus) in the Kalinin district of the Far East were said to represent a "geographical variety of $R$. siberica" $(152,160)$.

Geographically, D. nuttalli Olenev ranges through central and eastern Siberia, Soviet republics of central Asia, northern Mongolia, adjacent parts of China, and eastern Tibet, Ecologically, it occurs in cisalpine and alpine steppes, forested and desert steppes, and in the dunes of Tuva, ASSR (228$230,233,235$ ). Teng (296) investigated the biology, ecology, and life cycle of $D$. nuttalli in Inner Mongolia. Transovarial transmission and long term retention of $R$. siberica in $D$. nuttalli has frequently been reported. In a study of tick typhus and $D$. nuttalli in the Krasnoyarsk area, where 200 to 600 cases are recorded annually by the sanitary-epidemiological station (173), decisive factors affecting the incidence of human disease in a specific community are annual population cycles of the small mammals which serve as hosts for immature stages of $D$. nuttalli and the abundance of domestic animals available as hosts of the adult ticks (174).

D. marginatus (Sulzer) inhabits shrubby areas and low forests and marshs in lowlands and alpine steppes and the southern semidesert area, from northern Kazakhstan, Kirgizia, and Iran (1), through the Altai mountains

${ }^{4}$ The close geographical relationship of cottontail rabbit (Sylvilagus spp.), Dermacentor spp., and Rocky Mountain spotted fever in the United States has also been noted [Jellison, W. L. The geographical distribution of Rocky Mountain spotted fever and Nuttall's cottontail in the western United States. Public Health Rept., U. S., 60, 958-61 (1945)\}. In the subtropics and tropics of the Americas, the disease occurs within the range of cottontail rabbits but Dermacentor ticks are usually absent. 
(228) to Central Europe $(15,165)$ [see map and discussion in Schulze (264)]. Where the range of the western $D$. marginatus gives way to that of the eastern $D$. silvarum in western Siberia, a gradually increasing west-to-east degree of hybridization of these species is shown by spiracular plate irregularities (238). D. silvarum extends from Lake Baikal and the Kemerov and Novasibirsk areas eastward to the Primorsk region (Sea of Japan) and into northern Mongolia. An inhibitant of forest-steppe zones, it is most numerous in birchaspen marshs, glades in mixed forests, cultivated areas in taiga forest, and other localized dense shrubs and second growth forest. The basic ecological and biological work on $D$. silvarum (and $H$. concinna) in relation to tick typhus in the Far East of the USSR, commenced by Preobrazhensky (242), has been continued by Kuaglin, Somov, Shapiro, and others.

Dermacentor pictus Hermann has approximately the same range as $D$. marginatus, and may be found together with it in some forest steppes, but is less common in open steppes. D. pictus occurs in mixed and deciduous forests wet meadows, second growth forest, and forest glades, rarely in taiga forest. It endures only moderate dryness and moderate air humidity though its eggs survive in pools of rainwater. For accounts of $D$. pictus in central Europe, see Babos (15) and Mačička, Nosek \& Rosický (164). In western Europe, this tick is referred to as D. reticulatus (Fabricius) (10).

Haemaphysalis (Aboimisalis) punctatc Canestrini and Fanzago ranges through much of Europe, the northwestern corner of Africa, and southwestern Asia. The possibility that other species such as $H$. ( $A$.) cornupunctata Hoogstraal and Varma, or undescribed species, may routinely be identified as $H$. punctata by workers in the mountains of southern USSR, remains to be investigated. A species found in open mourttainous areas, steppe lands, semideserts, and deserts, $H$. punctata adults parasitize large wild and domestic mammals, including man. Bird hosts frequently carry immature stages long distances during migration [pertinent literature was listed by Hoogstraal (113)]. Rodents and other small mammals, and sometimes reptiles, are also infested by larvae and nymphs. Adults are generally active chiefly during fall, early and late winter, and spring; larvae and nymphs feed from spring to autumn [see Anastos (6) for other details and summary of literature]. According to Krontovskaya and others (148), this species, together with $D$. margina$t u s$, is an important vector of $R$. siberica in the foothills and valleys of Kirgizia, where its bionomics have recently beerl studied $(95,262)$.

Haemaphysalis $(H$.$) concinna Koch is widely distributed in forests of$ temperate Eurasia, from the Atlantic Ocean to islands in the Sea of Japan (285), and occurs in Kirgizia (96) and other southern republics of the USSR $(7,236)$. This species also requires taxonomic review. It is found chiefly in deciduous and mixed forests, grass tussock swamps, birch-aspen groves, and alpine taiga forest. Adults feed on large wild and domestic mammals; immature stages infest smaller mammals and birds, sometimes reptiles or domestic goats, sheep, and cattle. Adults and nymphs parasitize humans. All stages are active from spring to autumn; peak adult activity is in early 
summer (June). Ecologically and epidemiologically, H. concinna is of ten associated with $D$. silvarum. For further biological details concerning this species in eastern USSR (Primorsk, or Maritime Territory) where it has been incriminated in the epidemiology of both spring-summer encephalitis and of tick typhus, see page 273 of Hoogstraal (113). H. concinna was first shown to be a reservoir of $R$. siberica in 1941 (326). During the study of an old, active tick typhus focus in Kalinin District, four strains of $R$. siberica were isolated from $H$. concinna and one strain from $D$. silvarum (152). On one island in the Sea of Japan, three other strains were isolated from $H$. concinna, two from brains of Microtus fortis, and one from a human patient. On another island, strains were recovered from $M$. fortis. Serological evidence of infection in cattle and in $D$. silvarum was obtained on the first island. These strains were not distinguishable from each other but were said to differ from $R$. siberica strains of other areas of the USSR [see also (160)].

Haemaphysalis $(H$.$) japonica douglasi Nuttall and Warburton recently was$ found to be infected by $R$. siberica (152). Isolations were made from ticks parasitizing "spotted deer" (presumably Axis a. axis, bred for "medicinal properties" of their horns) on a peninsula extending into the Sea of Japan. Serum of the host deer contained complement-fixing antibodies to $R$. siberica. The recovered strains were reported to differ from those taken elsewhere in northern Asia (see paragraph above on $H$. concinna). Certain biological details concerning $H$. japonica douglasi were reviewed on page 273 of Hoogstraal (113). Additional details from more recently translated papers are epidemiologically notable. Some males of this species overwinter attached to the ears of cattle or deer, but do not feed at this time (20). In a bionomical study of the peninsular focus, Somov \& Shestakov (283) frequently collected all stages of $H$. japonica douglasi on vegetation in valleys and foothills with rich grass growth and shrub thickets but rarely on exposed slopes. Larvae, nymphs, and adults of different generations each overwintered on the ground and became active in spring (adults and nymphs, early March; larvae late April or early May) and maximum densities of adults and nymphs were found in April and May. Maximum larval numbers occcurred in late May with a second rise in late July, owing to the presence of newly hatched broods. Tremendously heavy infestations of adults and nymphs of this species and of $H$. neumanni Doenitz (which appears to not have been investigated in relation to $R$. siberica), and lesser numbers of larvae, were recorded from spotted deer which are numerous on breeding farms in this area. Larvae infested many birds and small mammals, chiefly the Asiatic chipmunk, which is the most common small mammal of the region. Other adult hosts were cattle, horses, roe deer, bears, foxes, racoons, and wildcats. Larvae, nymphs, and adults attack humans and a shepherd who experienced a mass infestation of larvae later suffered from acute dermatitis. Larvae feed on humans for three or four davs.

Hyalomma asiaticum subsp. larvae and nymphs, which are common in burrows of the red-tailed jird (Meriones erythrourus) in and near collective 
farms and towns of southwestern Kirgizia, were recently found to be infected by $R$. siberica, strains of which were recovered from the ticks and rodents (247). H. asiaticum is a two-host tick that parasitizes small rodents, ground squirrels, and hedgehogs in their burrows and other shelters in desert and semidesert zones of southern USSR, Afghanistan, Iran, and Iraq. Adults feed on domestic mammals and gazelles. When parasitizing lambs (153), adults may cause considerable inflammation and become completely covered by scabs. This tick can maintain $R$. siberica in its body for at least two years. The agent is transmitted trans-stadially and to subsequent generations transovarially. Its virulence is unaffected when the reservoir tick feeds to full engorgement on an immune host or when it feeds partially on an immune host and later completes the meal on a nonimmune host (100). [I am presently preparing a review of the $H$. asiaticum complex].

Rhipicephalus sanguineus (Latreille) has provided the most westerly record of infection by the agent of Siberian tick typhus. In Armenia, Kotsynian (145) recovered strains from $R$. sanguineus from sheep and dogs, and from $D$. marginatus of cattle. From these limited data, the Armenian focus appears possibly to differ somewhat in epidemiological characteristics from those in Siberia and the republics of central Asia.

\section{Boutonneuse Fever (Subgroup B)}

Boutonneuse fever, caused by Rickettsia conori and also known as South African tick typhus, Kenya tick typhus, Marseilles fever, Indian tick typhus, and by numerous other local names, is widely distributed in Africa. It has only recently been discovered to be present in Egypt (114). Elsewhere, it has been reported from European areas near the Mediterranean, Israel, Turkey, Crimea, northern and southern India, Burma, Malaya, Thailand, and Vietnam. The name refers to the characteristic buttonlike lesion at the point where the vector tick attaches to the humarl skin.

Owing to paucity of laboratories equipped for rickettsial research, much of the available information on this disease is circumstantial. In Africa it of ten derives from clinical episodes experienced by European residents or visitors. The extensive rash that characterizes $R$. conori infections is difficult to detect in Africans. Anyone who has experienced or witnessed a typical case of boutonneuse fever is impressed by the acute suffering of the patient and by the prolonged period leading to full recovery. Mild cases also occur in Africa, and appear to be the rule rather than the exception in Asia. Few fatalities result from boutonneuse fever. The incidence of recognized infection is generally, though not always, sporadic.

Throughout the history of boutonneuse fever, various groups of microbiologists have cast doubt on the importance of results of other investigators' research and have stressed that their own findings show the true disease transmission pattern. Reviewers have been particularly prone to emphasize these so-called discrepancies. In retrospect, this situation appears to have resulted from a combination of several simple factors. Experimental samples 
have almost always been small and highly selective while conclusions have often been broad and sometimes dogmatic. Practically no extensive epidemiological studies have been attempted. Earlier laboratory methods were not sufficiently sophisticated to reveal all of the details expected of them. The emphasis placed on certain differences in rickettsial strain virulence and in clinical severity obscured the overall epidemiological picture. However, when results of separate studies are woven together, without their accompanying discussions and conclusions, they sometimes provide a clear picture of natural cycles of the disease and of man's involvement under specific local circumstances.

Recent studies of $R$. conori strains from South Africa, Kenya, Northwest Africa, and Kashmir (India), in which the toxin-neutralization test in mice (23) and serological and cross-protection tests $(35,325)$ were employed, have shown no significant strain differences. Though epidemiological patterns, virulence of rickettsial strains, and severity of clinical symptoms of boutonneuse fever differ, they appear to be comparable to those characteristic both of Rocky Mountain spotted fever in the Americas and of Siberian tick typhus in the USSR. Extensive experiences with these agents and their clinical manifestations has led American and Russian specialists to agree in considering $R$. conor $i$ as a single rickettsial species and boutonneuse fever as a single clinical entity. The French school still regards this subject differently (91).

The transmission patterns of boutonneuse fever, Rocky Mountain spotted fever, and Siberian tick typhus, with all their variables, have much in common. The reader should keep this in mind, for we have chosen to present some of the most recent developments concerning boutonneuse fever on a geographical basis, from South to North Africa and from western Europe to eastern Asia, in the order stated, rather than to develop the picture of this disease from the standpoint of the roles of the reservoirs, vectors, ecological situations, and human victims. Most of the tick species reported to be involved in the epidemiology of boutonneuse fever [except $A$ mblyomma hebraeum and Rhipicephalus pulchellus) have been reviewed previously (112, 113) or herein (Dermacentor spp.)] and are not further discussed below.

In the Republic of South Africa, boutonneuse fever is encountered chiefly in the Transvaal veld and in the eastern coastal lowlands. Mild, severe, and sometimes fatal cases occur in both urban and field-acquired illness $(83,84$, 87). Urban cases, reported throughout the year, are associated with dogs infested by adults of Haemaphysalis leachii (Audouin) and by all stages of Rhipicephalus sanguineus (Latreille). Human infection in cities is of ten caused by contamination of the skin or of the eyes from rickettsia-bearing ticks crushed while deticking dogs (87).

The Appleton strain of $R$. conori, isolated from a sick puppy that had been taken on a picnic to the riverside 16 miles north of Pretoria $(3,168,169)$, proved to be identical to other $R$. conori strains from southern and northwestern Africa. Although local strains survived in experimentally infected 
dogs for some time, they did not multiply in these animals, which do not appear to play an important reservoir role in South Africa (169). In the northern suburbs of Johannesburg, a considerable proportion of the striped mice (Rhabdomys pumilio) and vlei rats (Otomys irroratus) investigated by Gear (84) gave serological evidence of $R$. conor $i$ infection and a strain was isolated from the brain of a vlei rat.

Larvae and nymphs of both $H$. leachii and $R$. sanguineus acquire the agent while feeding on an infected host. They transmit the rickettsiae during feeding in the following stages and females transmit these agents transovarially to the subsequent generation $(85,86,88,180)$. Transovarial transmission to the fourth generation was demonstrated in $H$. leachii. The larvae and nymphs of $H$. leachii usually parasitize burrow-inhabiting rodents, thus the rickettsial strain isolated from adults of this species taken from a dog (88) may have been acquired transovarially or from infected rodents. The reported cases of natural infection in $R$. sanguineus may have derived from (a) dogs that had also harbored infected $H$. leachii, (b) $R$. sanguineus adults that had fed, in the larval or nymphal stage, on infected urban rodents, or (c) agents inherited transovarially from the parent ticks.

Boutonneuse fever is widespread in the South African veld, where picnickers, travellers, and agricultural workers become infected, most commonly in spring and autumn. Although the chief vectors appear to be Amblyomma hebraeum and Rhipicephalus appendiculatus in this area, Gear (84) has stated that: "It seems probable that most species of ixodid ticks are capable of transmitting the disease" and since "Hereditary transmission (apparently) may continue indefinitely it seems probable that no mammalian reservoir is therefore necessary for preserving the infection in nature. However it has been surmised that veld rodents may help in disseminating the infection." It would be interesting to see whether or not more extensive experimental laboratory and field studies would support this epidemiologically important hypothesis.

Before recognition of urban boutonneuse fever in South Africa, this disease has been thought to originate chiefly in the veld and the agent was considered to differ from that elsewhere in Africa. Immature stages of $A$. hebraeum and $R$. appendiculatus swarm on humans visiting the veld, and a few rickettsial isolations were made from these species (221-227, 305). Nymphs of Hyalomma m. rufipes Koch from a hare (Lepus capensis) (180) and adults of this species from domestic cattle were also found to be infected (78); both tick lots were reported as $H$. aegyptium.

South African strains of $R$. conori sent to the Rocky Mountain Laboratory following inoculation into Ornithodoros moubata were recovered in sus. pensions of some of these ticks 32 days after shipping and produced typical reactions of infection following inoculation into guinea pigs (191).

Amblyomma hebraeum Koch is confined to parts of South Africa (297) Mozambique, Bechuanaland, Southern Rhodesia, and Nyasaland where acacia or mopane savannahs exist, but is absent from open savannahs. Its 
immature stages feed on birds, reptiles, and smaller and large mammals (including man); adults feed on medium and large size wild and domestic mammals (298). A male of this species was once found on a cow in Bulgaria, presumably having been transported there as a nymph on a migrant bird from southern Africa (200). Assuming that ticks of this species are fairly frequently infected by $R$. conor $i$ and that the rickettsia is maintained through several generations of this tick as South African specialists suggest, the potential importance of even a single finding such as this in Bulgaria is easily recognized.

Boutonneuse fever has been reported from numerous localities between South Africa and Kenya. It has been said that no newcomer to the vicinity of Lourenço Marques, Mozambique, escapes infection by this disease (305). One of the earliest reports of this illness was from Mozambique in 1911.

Recent studies on the epidemiology of feral boutonneuse fever in Kenya (104-108) were summarized in some detail by Heisch et al. (108). $R$. conori was isolated from $H$. leachii and Rhipicephalus simus Koch, the immature stages of which parasitize burrow-inhabiting rodents. Other isolations were from Amblyomma variegatum (Fabricius) (immature stages on birds and small mammals), R. e. evertsi Neumann (a two-host species, with immature stages usually found on the same large mammals as the adults), and Hyalomma albiparmatum Schulze (immature-stage biology unstudied). No rickettsiae were isolated from several other tick species, among them fairly large samples of $R$. sanguineus and of $R$. pulchellus Gerstäcker. The samples were collected from very limited sources, thus the implications from these widely quoted negative results are equally limited.

In Heisch's (109) Kenya studies, strains of $R$. conor $i$ were isolated by inoculation of spleen and brain material into guinea pigs, from the Nile grass rat (Arvicanthis niloticus), domestic rat (Rattus rattus), multimammate rat (Mastomys natalensis), swamp rat (Otomys sp.), harsh-furred mouse (Lophuromys flavopunctatus), four-striped grass-mouse (Rhabdomys pumilio), singlestriped grass-mouse (Lemniscomys striatus), and grass rat (Aethomys kaiseri). Each of these rodents is a characteristic host of immature $H$. leachii and $R$. simus ticks. In small samples of several larger wild and domestic animals, some evidence of antibodies to $R$. conori was obtained.

Heisch et al. (109) maintained that the dog's role in the epidemiology of this disease in Kenya is that it sustains populations of known tick reservoirs and vectors such as $H$. leachii (adults only) in close proximity to man. Earlier, Roberts (256-258), working from the viewpoint that this disease in Kenya is associated with household dogs and their tick parasites, found that "each case investigated gave a history of having been in contact with dogs (and) evidence was obtained to establish the fact that the disease was transmitted through the bite of ...R. sanguineus and that a large number of houses where cases had occurred harbored enormous numbers of this species." In these instances, emulsions of household $R$. sanguineus inoculated into guinea pigs produced symptoms typical of boutonneuse fever in these ani- 
mals. During this period, the prevalence of the disease in staff houses of the Kenya and Uganda Railways, and the long convalescent period, disrupted the normal functions of the railroad.

During World War II, Dick \& Lewis (68), working in East Africa with boutonneuse fever in British troops and European prisoners of war, isolated the agent from $H$. leachii and $R$. simus and laid great stress on the importance of these two tick species in contrast to $R$. sanguineus, $R$. pulchellus, and other species from which they failed to recover rickettsiae.

Clinical aspects of boutonneuse fever in Kenya were described by Craddock (64), who also mentioned (65) that in 39 cases seen by him only two showed no apparent sign of tick bite. In one verified case, a specimen of $R$. pulchellus Gerstäcker (stage not stated) was removed from the patient's interdigital cleft, where a typical eschar subsequently developed. The involvement of $R$. pulchellus is interesting, owing to failure of attempts to isolate rickettsiae from several lots of wild specimens of this species (108, 256-258). Larval "pepper ticks" of this species of ten swarm on humans walking paths through fairly dry, hot savannah and semidesert areas east of the Rift Valley in East Africa. Adults (299) and immature stages $(308,309)$ both feed on almost any moderate- to large-size wild or domestic mammal or bird.

In Ethiopia (218), significant antibody titers against $R$. conor $i$ were found in sheep and goats from the Adama area. Inoculation of adult tick samples from cattle into guinea pigs provided evidence of infection in two lots of Amblyomma variegatum from Nazareth and the Awash River, in one lot of A. cohaerens Doenitz from Awasa Valley, and in one lot of Rhipicephalus simus from Lake Koka. Other serological and immunological results gave evidence of infection in adults of $R$. e. everisi and $R$. pulchellus from Awash River, A.cohaerens from Lake Awasa, $A$. variegatum pooled from four localities, Hyalomma marginatum rufipes pooled from eight localities, and Boophilus decoloratus from between Nazareth and Lake Langano. Earlier, Charters (56), in discussing boutonneuse fever cases from near Harrar, mentioned infestation of patients by $A$. variegatum, $A$. marmoreum group [probably $A$. sparsum Neumann; see Theiler \& Salisbury (300)], $R$. pulchellus, and $R$. simus. Severe clinical cases associated with $R$. sanguineus have been reported from Asmara and Gondar (53).

A few cases of boutonneuse fever have been observed in the Sudan (240) and in Nigeria and the Gold Coast (77).

Much of the early research on $R$. sanguiveus in the Mediterranean Basin was done in northwestern Africa (Algeria and Morocco) and in Greece by Blance, Brumpt, Caminopetros, Durand, and others. The major details have been well summarized on pages 1152 to 1156 of Brumpt's Precis de Parasitologie (39). It has been asked whether $R$. sanguineus more frequently parasitizes humans in northwestern Africa than it does elsewhere in the world. No evidence that this is true has been presented. Following the same query in France (see below), other tick species were found also to maintain the bou- 
tonneuse fever cycle in nature. Possibly similar factors are involved in Morocco and Algeria as well as in other areas where only $R$. sanguineus has thus far been incriminated in the natural history of boutonneuse fever.

Early workers on boutonneuse fever in France concentrated on the relationships between the agent of this disease and $R$. sanguineus [see (91)]. Under experimental conditions, however, French samples of this tick were little attracted, if at all, to proffered human bait. This fact, as well as the discrepancy between the numbers of reported clinical cases and the paucity of reports of $R$. sanguineus biting man in France, led Sigalas \& Lamontellerie (270) to the uneasy conclusion that something was amiss in the recognized epidemiological picture of this disease in their country. The apparent answer to this problem was shortly forthcoming. It now appears that, in addition to $R$. sanguineus, Ixodes ricinus (Linnaeus), I. hexagonus Leach, Dermacentor marginatus (Sulzer), and D. reticulatus (Fabricius) (see D. pictus, p. 394) also play parts in maintaining the boutonneuse fever cycle in nature in France (91-93). Indeed, following the recent myxomatosis epidemic in Europe (76) the resulting drop in numbers of rabbits and their ticks was paralleled by a drop in the incidence of boutonneuse fever. It is interesting that three males of Amblyomma variegatum, a species that has been found to be naturally infected in Kenya and in Ethiopia, were once recovered from a dog in southwestern France (159) and that this tick species is found on migrant birds en route from Africa to Europe (116).

Numerous Italian reports of boutonneuse fever, in association with $R$. sanguineus and from contamination of the eyes or skin by contents of crushed, infected ticks, have been listed by Starkoff (291).

Bulgarian foci (of "Marseilles fever") are known in 82 southern and Black Sea coast towns and villages where $R$. sanguineus occurs in association with domestic dogs (199). In endemic districts, "a considerable percentage of dogs have specific antibodies in high titers in their serum (and) could be infected experimentally and rickettsiae could subsequently be isolated from the blood." Trans-stadial and transovarial transmission of the agent as well as transmission to guinea pigs through feeding processes was demonstrated in $R$. sanguineus. This would appear to be a definitive study establishing the epidemiological role of dogs and $R$. sanguineus under Bulgarian conditions. Ten strains of $R$. conor $i$ were isolated from 301 ticks (species not mentioned), from hares (Lepus europaeus), domestic dogs and farm animals, and human patients. Of 108 human cases clinically diagnosed as boutonneuse fever from 1948 to 1956,107 were serologically confirmed. Incidence of the disease between May and September was correlated with seasonal fluctuations in population densities of $R$. sanguineus, which are highest in July and August. We have already noted (page 398) that a specimen of Amblyomma hebraeum, a species considered to be an important vector of $R$. conor $i$ in the veld of South Africa, has been taken feeding on a cow in Bulgaria.

Results of serological tests in Turkey suggest that boutonneuse fever ranks among the significant rickettsial infections in this country $(201,202)$. 
In the Crimea, where boutonneuse ( $=$ Marseilles) fever was first recognized in 1936, it is a "backyard" disease associated with $R$. sanguineus and domestic dogs. Notably, rodents are not mentioned in literature available to me. The disease is reported to health authorities each year in Sevastopol and other Crimean towns, and in other localities on the Black and Caspian Sea coasts of Transcaucasia. The incidence of cases, which are reported from April to November, with peak number in June and in August, is correlated with seasonal fluctuations in infestation of dogs, which are host to the larvae, nymphs, and adults of $R$. sanguineus. In Sevastopol, where complementfixing antibodies to $R$. conor $i$ were detected in 3.7 per cent of healthy human residents, 61.7 per cent of dogs examined were tick infested, with an average of 34 adults per dog in June and over 300 larvae and nymphs per dog in August. Complement-fixing antibodies to $R$. conori were found in 31.2 per cent of dogs examined in the city and in 24.1 per cent of those in the suburbs. $R$. conori was recovered from 5 of 18 tested batches of $R$. sanguineus (151). A certain number of cases are misdiagnosed as other illnesses (188).

In the northern mountains of West Pakistan, rickettsiae of the spotted fever group have recently been isolated from Rhipicephalus turanicus Pomerantzev and from immature Dermacentor sp. by field teams of the Department of Microbiology and the International Center for Medical Research and Training of the University of Maryland School of Medicine. Definitive identification of the rickettsial strains is pending (314).

Boutonneuse fever (Indian tick typhus) has been shown to be widely distributed both in northern and southern India by Kalra (125), who reviewed the earlier history of the disease and presented results of recent surveys made in the warm and cold parts of India. Additional localities were mapped by Shortt \& d'Silva (269) and Finnegan (79). Rickettsial strains have been isolated from Haemaphysalis sp. (reported as $H$. leachii indica) in Imphal, Ixodes sp. (reported as I. ricinus) in the Kumaon Hills, and $R$. sanguineus in Kashmir. Reports of Hyalomma aegyptium in relation to this disease refer to any one of several other Hyalomma species, but not to H. aegyptium (124). A rickettsial strain sent to the Rocky Mountain Laboratory in $R$. sanguineus from dogs in north-central India where an epidemic had recently occurred (126), was identified as a member of the spotted fever group (219). As we have mentioned in introductory paragraphs of the section on boutonneuse fever, results of all tests by modern microbiological methods show the Kashmir strain of $R$. conori to be identical to those from Africa.

In southeast Asia, investigations of rickettsial agents and infections other than scrub typhus commenced about 1950. Serological evidence and clinical diagnosis of scattered, mild human cases were reported from Vietnam (30, $52,57,58,183)$ although, in the opinion of a reviewer of two of these reports $(57,58)$, the epidemiological and clinical descriptions are entirely consistent with the diagnosis of dengue $(171,172)$.

Spotted fever group rickettsiae (TT-118) have been isolated from a mixed pool of larvae of Ixodes sp. and Rhipicephalus sp. from Rattus rattus trapped 
in Chiengmai Province, Thailand (72). On the basis of complement fixation tests employing species-specific antigens, TT -118 appears to be more closely related to $R$. conori and Indian tick typhus than to other members of the group. Since cross-vaccination challenge tests in guinea pigs carried out at the Walter Reed Army Institute of Research, Washington, D. C., reveal definite differences between $R$. conori and the agent of Indian tick typhus, workers there are not yet willing to accept their common identity. They hope to complete the testing necessary to define these relationships more clearly in about a year's time.

Before the Japanese occupation during World War II, cases suspected of being boutonneuse fever were reported from Burma where $R$. sanguineus is known to occur on dogs (313), but further investigation appears not to have been made. There are no reports of boutonneuse fever from Cambodia, Laos, or the Philippine Islands, but Marchette (167) believes that it probably occurs in these countries.

In Malaya, Marchette (167) has demonstrated that the basic cycle of boutonneuse fever ("tick typhus") occurs in the mammals and ticks of climatic climax forests. Giant and spiny-furred forest rats (Rattus rajah, $R$. surifer, $R$. whiteheadi, $R$. sabanus, $R$. muelleri, $R$. edwardsi), tree shrews (Tupaia glis), and Ixodes granulatus Supino and Haemaphysalis spp. ticks are involved in the cycle. Presumptive isolations of the rickettsiae were made from $R$. muelleri and R. whiteheadi and from I. granulatus and Haemaphysalis spp. in climax Dipterocarpus forests. The other species of forest-inhabiting mammals were implicated on serological grounds. In agricultural lands, presumptive isolations from $R . r$. argentiventer and $R . r$. diardi, and the high prevalence of serological positives in urban rats indicates that a cycle also exists in these situations. Marchette showed that forest rats, particularly $R$. bowersi, $R$. muelleri, and $R$. whiteheadi, wander into secondary scrub forest ecosystems where they may come into contact with semidomestic rodents (R. r. jalorensis and $R$. exulans) and exchange ectoparasites and rickettsiae. These, in turn, are in contact with mammals (Mus musculus, $R$. $r$. argentiventer, $R$. $r$. diardi, and Suncus murinus) of strictly man-dominated ecosystems such as farms, plantations, and urban areas. Serological evidence indicates that ground- or bush-dwelling birds of scrub forests [white-throated bulbul (Criniger phaeocephalus), yellow-vented bulbul (Pycnonotus goiarier), large olive bulbul ( $P$. plumosus), and crested brown bulbul ( $P$. eutilotus)] may become infected, thus forming another potential link through which rickettsiae may spread between forest and urban animals.

Using data from tick samples collected for the study by Marchette and other workers at the Institute for Medical Research, Kuala Lumpur, we (115) have shown that some of the most common Haemaphysalis tick species of the forest mammals mentioned above [H. (Kaiseriana) semermis Neumann and $H$. ( $K$.) papuana nadchatrami Hoogstraal, Trapido, and Kohls] frequently infest people and dogs travelling through the forest and are carried by these hosts to houses in villages and cities. These two tick species are exceedingly 
common, as larvae and nymphs, on forest rodents and other small mammals of the Malaya Peninsula, and are also recorded from nearby islands, southern Thailand, Borneo, and Sumatra and Java (Indonesia). Adults infest almost any larger mammal in the forest (human, tiger, leopard, wild dog, wild boar, bearded pig, tapir, etc.) and sometimes also parasitize domestic mammals (pig, horse, buffalo, and cow) in or near forests. Both species of ten occur together on the same host and each of their developmental stages is active during all seasons of the year. The host-parasite relationships of a number of other species of potential interest in respect to boutonneuse fever are mentioned in a continuing current series of reports entitled "Studies on Southeast Asian Haemaphysalis Ticks" in the Journal of Parasitology [see (115)].

Marchette (167) also collected Dermacentor auratus Supino on mammals in slightly greater numbers than Ixodes granulatus Supino, as well as smaller numbers of other species [R. sanguineus, A mblyomma testudinarium Koch (crawling on humans), and H. bispinosa Neumann (from a sentinal white rabbit in a cattle field)].

The edaphic climax formations of fresh-water swamp and mangrove swamp forests in Malaya were found (167) to play a minor role in the ecology of tick-borne rickettsiae. The limited mammalian fauna of mangrove swamp forests is generally isolated from climatic climax forests by wide tracts of intensively worked agricultural lands, thus there is little chance of contact with basic forest cycles. Fresh-water swamp forests adjacent to primary Dipterocarpus forests, secondary forests, and plantations are available to rodents from each of these ecosystems and may harbor secondary but apparently not independent cycles of the rickettsia. Marchette's extensive survey and intensive study, the most elaborate yet devoted to boutonneuse fever, is an excellent model for research on this subject in other tropical areas with a complex fauna.

\section{Maculatum Agent (Subgroup B)}

Rickettsial strains, mildly pathogenic for guinea pigs, were isolated in 1937 from Amblyomma maculatum Koch collected from cattle in Texas (190, 194). Subsequently, other isolations were made from $A$. maculatum from Texas, Mississippi, and Georgia, and serological evidence identified this agent as a member of the spotted fever group (156). Philip \& White (215) isolated eight strains from these ticks taken from sheep in Mississippi. Other tick species ( $D$. variabilis, $H$. leporispalustris, A. americanum, $I$. scapularis Say, $I$. cookei Packard) from the same geographical areas were uninfected. Recently, Lackman et al. (157) named this agent $R$. parkeri and demonstrated its close relationship to $R$. rickettsi. Therefore we mention this agent in spite of lack of evidence of human infection. A. maculatum, or the Gulf Coast tick, inhabits chiefly coastal areas of southeastern United States (63) and Mexico (111) to northern South America (Columbia, Venezuela, and Ecuador). Adults feed on larger wild and domestic marnmals, occasionally on man. Larvae and nymphs attack a variety of birds an 1 also smaller wild mammals. 
The biology and economic importance of $A$. maculatum were summarized by Bishopp \& Hixson (31).

\section{Queensland Tick Typhus (Subgroup C)}

$R$. australis Philip [see (204)], the rickettsia causing Queensland tick typhus, was identified as a separate member of the spotted fever group by complement fixation tests (154). Lackman et al. (157) and Pickens et al. (220) have demonstrated the serologic relationship between this and other members of the spotted fever group and a particularly close relationship to $R$. akari, the agent of rickettsialpox. The disease caused by $R$, australis resembles rickettsialpox clinically (130).

The rickettsia was first isolated in 1944-45 from blood of two military patients who had been training in jungle warfare on the Atherton Tableland of northern Queensland (8). Here, in belts of dense forest interspersed in grassy savannah on the 2000 -foot high plateau, the soldiers were bitten by adult and larval Ixodes holocyclus, especially during the early spring rains of August and September. Another patient was a women who had lived for a few weeks in a secondary scrub area of northern Queensland (37). Subsequent cases were reported from southern Queensland $(130,179,237)$. One carefully observed patient (130) was bitten on the neck by $I$. holocyclus during a short visit to the forested Mount Nebo district near Brisbane. She removed the tick within two hours after it had attached. If this particular tick transmitted the infection, this is a striking demonstration of rapid tick-transmission of a rickettsial agent, a phenomenon that should be investigated experimentally. Most authors stress that human cases probably are often misdiagnosed and are likely to be more numerous than reported.

Result of complement fixation tests of sera from marsupial mammals on the Atherton Tableland suggest that several species act as rickettsial reservoirs (75). These are the short-nosed bandicoot (Isoodon obseulus), longnosed bandicoot (Parameles nasuta), Johnstone's opossum (Trichosurus vulpecula johnstonii), rufous rat-kangaroo (Aepyprymnus rufescens), and Atherton uromys (Uromys sherrini).

Tick species, in addition to Ixodes holocyclus Neumann, reported from the Atherton highland are I. tasmani Neumann, Haemaphysalis humerosa Warburton and Nuttall, $H$. bancrofti Nuttall and Warburton, Rhipicephalus sanguineus (Latreille), and Boophilus microplus (Canestrini). Although Fenner (75) failed in an attempt to isolate rickettsiae from $I$. holocyclus, $I$. tasmani, or $H$. humerosa, the frequent removal of larval and adult $I$. holocyclus from tick typhus patients in northern and southern Queensland provides circumstantial evidence that this species may be an important vector. I. holocyclus is widely distributed in coastal and densely forested areas of Australia and is an unusually indiscriminate feeder, attacking almost any bird or mammal that comes its way $(255,261,265)$. Parasitism by females and nymphs sometimes causes tick paralysis in the host. Females are found at almost any time of the year but are most numerous from August to 
December, particularly during October and November. Nymphs are active chiefly through winter and early spring, larvae mainly in summer and fall. All published records of this species from outside Australia appear to be incorrect (255).

\section{Eastern and Western Montana Agents (Subgroup D)}

Little is known about these two apparently nonpathogenic rickettsiae which are reviewed here only because of their close association, revealed by the complement fixation test, to pathogenic members of the spotted fever group. Forty strains of the Eastern Montana agent, named $R$. montana by Lackman et al. (157), were recovered from $D$. variabilis together with others from $D$. andersoni (24). Guinea pigs injected with these strains developed high titers of complement-fixing antibody but little, if any, antitoxin against a virulent $(\mathrm{R})$ strain of $R$. rickettsi. Strains were recovered from approximately 7 per cent of $D$. variabilis in each of five sample localities in eastern Montana.

The unnamed Western Montana agent, reported by Price (245) from D. andersoni, is also included in this subgroup (157).

\section{SCRUB TYPHUS}

Rickettsia tsutsugamushi is closley associated with trombiculid mites and their rodent hostsover the whole of the Oriental and portions of the Palearctic and Australian zoogeographic regions $(13,14,278)$. R. tsutsugamushi fails to multiply or to survive in Ornithodoros moubata. A claimed isolation of this agent from naturally infected Ixodes ticks from Rattus rattus in the outskirts of Shaowu city, in the mountains of northern Fukien, China (149), requires corroboration. The tick strain was said to be identical to $R$. tsutsugamushi, isolated from patients suffering from typical scrub typhus on P'ingt'an Island in Fukien.

\section{MISCELLANEOUS AGENTS AND DISEASES}

The name Rickettsia pavlovskyi, proposed by Korshunova in 1955 for the agent of hemorrhagic nephroso-nephritis [sec: Philip \& Burgdorfer (211) for references], was stated by $Z$ drodovskii \& Golinevich (325) to be "premature." Although the supposed viral agent of this disease has not yet been isolated, rickettsiae and ticks are not considered by contemporary authorities to be involved in the epidemiology of this disease (113) [see also: Casals, J., Hoogstraal, H., Johnson, K. M., Shelokov, A., Wiebenga, N., and Work, T. H. A current appraisal of hemorrhagic fevers in the U.S.S.R. Am. J. Trop. Med. Hyg., (1966), in press)].

A disease of Ukrainia, referred to as tick-borne paroxysmal rickettsiosis, has a benign course unaccompanied by dermal rash, a negative Weil-Felix reaction, and a tendency to brief recurrences after the initial febrile episode (325). So far as I am aware, the agent has not been named or categorized in relation to other rickettsial species. The vector is Ixodes ricinus and natural 
infections have been found in the red forest vole (Clethrionomys glareolus) on which the immature stages of this tick commonly feed in rural areas of Ukrainia. Transovarial transmission of the agent in $I$. ricinus has been demonstrated.

\section{LITERATURE CITED}

1. Abbassian-Lintzen, R. A preliminary list of ticks occurring in Iran and their distributional data. Acarologia, 2, 43-61 (1960)

2. Aitken, T. H. G., Omardeen, T. A., and Gilkes, C. D. The 1958 cayenne tick outbreak. J. Agr. Soc. Trinidad E Tobago, 58, 153 57 (1958)

3. Alexander, R. A., Mason, J. H., and Neitz, W. O. Studies of the ricket. tsias of the typhus-Rocky-Mountain-spotted-fever group in South Africa. 1. Isolation of strains. Onclerstepoort J. Vet. Sci. Animal Indus., 13, 19 23 (1939)

4. Alifanov, V. I. Winter parasitism of ixodid ticks on livestock in Omsk Oblast. (In Russian). Med. Parazitol. Moscow s. Parazitol. Zametk., 23, 268-69 (1954); (In English: NAMRU 3-T138)

5. Allred, D. M., and Roscoe, E. J. Life history of the tick Dermacentor parumapertus in Utah. J. Parasitol., 42, 516-22 (1956)

6. Anacker, R. L., Fukushi, K., Pickens, E. G., and Lackman, D. B. Electron microscopic observations of the development of Coxiella burnetii in the chick yolk sac. $J$. Bacteriol., 88, 1130-38 (1964)

7. Anastos, G. The ticks, or ixodides, of the U.S.S.R.-A review of the literature. $U$. S. Public Health Serv. Publ., 548, 397 pp. (1957)

8. Andrew, R., Bonnin, J. M., and Williams, S. Tick typhus in North Queensland. Med. J. Australia, 2, 253-58 (1946)

9. Aragão, H. B. Ixodidas brasileiros e de alguns paizes limitrophes. Mem. Inst. Oswaldo Cruz, 31, 759-843 (1936)

10. Arthur, D. R. Ticks. A monograph of the Ixodoidea. V. On the genera Dermacentor, Anocentor, Cosmiomma, Boophilus and Margaropus. (Cambridge Univ. Press, London, Engl., 251 pp., 1960)

11. Atwood, E. L., Lamb, J. T., and Sonenshine, D. E. A contribution to the epidemiology of Rocky Mountain spotted fever in the eastern United States. Am, J. Trop. Med. Hyg., 14, 831-37 (1965)

12. Audy, J. R. The localization of disease with special reference to the zoonoses. Trans. Roy. Soc. Trop. Med. Hyg., 52, 308-34 (1958)

13. Audy, J. R. The ecology of scrub typhus. In Studies in Disease Ecology, Chap. 12, 389-432, (May, J. M., Ed., The Hafner Press, New York, 1961)

14. Audy, J. R., and Harrisen, J. L. A review of investigations on mite typhus in Burma and Malaya, 1945-1950. Trans. Roy. Soc. Trop. Med. Hyg., 44, 371-404 (1951)

15. Babos, S. Die Zeckenfauna Mitteleuropas. (Akadémiai Kiadó, Budapest, 410 pp., 1964)

16. Bacha, W. J., Jr. The life history of Otobius lagophilus. J. Parasitol., 43, 560-65 (1957)

17. Badger, L. F., Dyer, R. E., and Rumreich, A. An infection of the Rocky Mountain spotted fever type. Identification in the eastern part of the United States. Public Health Rept. U. S., 46, 463-70 (1931)

18. Beck, D. E. Distributional studies of parasiticarthropods in Utah, determined as actual and potential vectors of Rocky Mountain spotted fever and plague, with notes on vector-host relationships. Brigham Young Univ. Sci. Bull., s. Biol., 1, 1-64 (1955)

19. Beck, D. E., Allred, D. M., and Brinton, E. P. Ticks of the Nevada test site. Brigham Young Univ. Sci., Bull, s. Biol., 4, 1-11 (1963)

20. Belikova, N. P. Material on the overwintering of ixodid ticks on animals. (In Russian). Trud. Dal'nevost. Fil. Akad. Nauk USSR, s. Zool., 3, 265-68 (1956); (In English: NAMRU3-T105)

21. Bell, E. J., and Philip, C. B. The human rickettsioses. Ann. Rev. Microbiol., 6, 91-118 (1952)

22. Bell, E. J., and Pickens, E. G. A toxic substance associated with the rickettsias of the spotted fever 
group. J. Immunol., 70, 461-72 (1953)

23. Bell, E. J., and Stoenner, H. G. Immunologic relationships among the spotted fever group of rickettsias determined by toxin neutralization tests in mice with convalescent animal serums. J. Immunol., 84, 171-82 (1960)

24. Bell, E. J., Kohls, G. M., Stoenner, H. G., and Lackman, D. B. Nonpathogenic rickettsias related to the spotted fever group isolated from ticks, Dermacentor variabilis and Dermacentor andersoni from eastern Montana. J. Immunol., 90, 770-81 (1963).

25. Belozerov, V. N. Day length as a factor determining the delay of egg-laying of females of Dermacentor marginatus (Sulz). (In Russian; Engl. sum.). Med. Parazilol., Moscow, 32, 521-26 (1963)

26. Belozerov, V. N. Diapause in ixodid ticks. (In Russian). In Reports of the 16th and 17th Annual Lectures to the Memory of $N$. A. Kholodkovsky (1963-1964) 12-33. (Akad. Sci. USSR, All-Union Entomol. Soc. Izd. Nauka Moscow-Leningrad, 97 pp., 1965)

27. Belozerov, V. N. A developmental stage of Dermacentor marginaius (Sulz.) sensitive to photoperiodic influences. (In Russian; Engl. sum.). Med. Parazilol., Mascow, 34, 52-57, (1965)

28. Belozerov, V. N., and Kvitko, N. V. Main features of photoperiodic reaction in Dermacentor marginatus Sulz. ticks. (In Russian; Engl. sum.). Zool. Zh., 44, 363-72 (1965); (In English: NAMRU3-T190)

29. Bertram, D. S. Rickettsial infections and ticks. Symp. Zool. Soc. London, 6, 179-97 (1962)

30. Beytout, D. Rickettsioses diagnostiquées par microagglutination de janvier 1962 a juin 1963 à Saigon. Bull. Soc. Pathol. Exotique, 57, 25763 (1964)

31. Bishopp, F. C., and Hixson, H. Biology and economic importance of the Gulf Coast tick. J. Econ. Entomol, 29, 1068-76 (1936)

32. Bishopp, F. C., and Trembley, H. L. Distribution and hosts of certain North American ticks. J. Parasilol., 31, 1-54 (1945)

33. Boero, J. J. Las garrapatas de la República Argentina (Univ. de
Buenos Aires, Dept. Editorial. 113 pp., 1957)

34. Bow, M. R., and Brown, J. H. Rocky Mountain spotted fever in Alberta, 1935-50. Can. J. Public Health, 43, 109-15 (1952)

35. Bozeman, F. M., Humphries, J. W., Campbell, J. M., and O'hara, P. L. Laboratory studies of the spotted fever group of rickettsiae. Med. Sci. Publ., Walter Reed Army Inst. Res. Wosh., 7, 7-11 (1960)

36. Brinton, E. P., Beck, D. E., and Allred, D. M. Identification of the adults, nymphs and larvae of ticks of the genus Dermacentor Koch in the western United States. Brigham Young Univ. Sci. Bull., s. Biol., 5, 1-44 (1965)

3i. Brody, J. A case of tick typhus in North Queensland. Med. J. Australia, 1, 511-12 (1946)

38. Brumpt, E. Longue conservation de 28 mois du virus du typhus de Sâo Paulo chez l'argasine Ornithodorus turicata. Non transmission par la piqure de cet acarien. Ann. Parasitol. Hum. Comp., 14, 621-28, 629-31 (1936)

39. Brumpt, E. Precis de Parasitologie, 6th ed. (Masson et Cie, Paris, 2138 pp., 1949)

40. Brumpt, E., and Desportes, C. Grande longévité du virus de la fièvre pourprée des Montagnes Rocheuses et de celui du typhus de Sâo Paulo chez Ornithodorus turicata. Ann. Parasitol. Hum. Comp., 18, 145-53 (1941)

41. Burgdorfer, W. Evaluation of the fluorescent antibody technique for the detection of Rocky Mountain spotted fever rickettsiae in various tissues. Pathol. Microbiol., Suppl., 24, 27-29 (1961)

42. Burgdorfer, W. Investigation of transovarial transmission of Rickettsia rickettsii in the wood tick, Dermacentor andersoni. Exptl. Parasitol., 14, 152-59 (1963)

43. Burgdorfer, W., and Lackman D. Identification of Rickettsia rickettsii in the wood tick, Dermacentor andersoni, by means of fluorescent antibody. J. Infect. Diseases, 107, 241-44 (1960)

44. Burgdorfer, W., Newhouse, V. F., Pickens, E. G., and Lackman, D. B. Ecology of Rocky Mountain spotted fever in western Montana. I. Isolation of Rickettsia rickettsii from wild 
mammals. A m.J. Hyg., 76, 293-301 (1962)

45. Bustamante, M. E., and Varela, G. Una nueva rickettsiosis en Mexico. Existencia de la fiebra manchada americana en los Estados de Sinaloa y Sonora. Rev. Inst. Salubridad Enfermedades Trop. Mex., 4, 189210 (1943)

46. Bustamante, M. E., and Varela, G. III. Estudios de fiebre manchada en Mexico. Hallazgo del Amblyomma cajennense naturalmente infectado en Veracruz. Rev. Inst. Salubridad Enfermedades Trop. Mex., 7, 75-78 (1946)

47. Bustamante, M. E., and Varela, G. Distribución del tifo y la fiebre manchada en la República Mexicana. Rev. Inst. Salubridad Enfermedades Trop. Mex., 8, 2-14 (1947)

48. Bustamante, M. E., and Varela, G. IV. Estudios de fiebre manchada en Mexico. Papel del Rhipicephalus sanguineus en la transmisión de la fiebre manchada en la Republica Mexicana. Rev. Inst. Salubridad Enfermedades Trop. Mex., 8, 13941 (1947)

49. Bustamante, M. E., Varela, G., and Ortiz Mariotte, C. II. Estudios de fiebre manchada en Mexico. Fiebre manchada en La Laguna. Rev. Inst. Salubridad Enfermedades Trop. Mex., 7, 39-48 (1946)

50. Camin, J. H. Relations between hostfinding behavior and life histories in ectoparasitic acarina. In Advances in A carology, I, 411-24. (Naegele, J. A., Ed., Cornell Univ. Press, Ithaca, N. Y., 1963)

51. Camin, J. H. Application of behavioral data to problems of laboratory rearing of parasitic acarines. A carologia, 6 (fasc. h. s.), 350-56 (1964)

52. Capponi, M. Rapp. Ann. Fonct. Tech., Inst. Pasteur, Viet Nam, 2324 (1956)

53. Cavazzi, G. Segnalazione di cinque casi di febbre bottonosa sull'altopiano etiopico. Boll. Soc. Ital. Med. Ig. Trop., 2, 5-9 (1943)

54. Cawley, E. P., and Wheeler, C. E. Rocky Mountain spotted fever. J. Am. Med. Assoc., 163, 1003-7 (1957)

55. Chang, R. S. M., Murray, E. S., and Snyder, J. C. Erythrocyte-sensitizing substances from rickettsiae of the Rocky Mountain spotted fever group. J. Immunol., 73, 8-15 (1954)

56. Charters, A. D. Tick-typhus in
Abyssinia. Trans. Roy. Soc. Trop. Med. Hyg., 39, 335-42 (1946)

57. Cluzel, P., and Desnues, P. Etude épidémiologique préliminaire d'une fièvre ex thématique bénigne dans les établissements de la marine à Saigon. Rev. Méd. Navele, Paris, 10, 7-20 (1955)

58. Cluzel, P., and Roux, M. Une nouvelle rickettsiose: la fièvre exanthématique urbaine de Saigon. Rev. Méd. Navele Paris, 8, 151-63 (1953)

59. Collins, D. L., and Nardy, R. V. The development and application of spray procedures for controlling the tick Dermacentor variabilis Say. Bull. N.Y. State Mus., Circ. 26, 37 pp. (1951)

60. Collins, D. L., and Nardy, R. V. Effect of DDT spray residues on larvae of the tick Dermacentor variabilis, Say. J. Econ. Entomol., 43, 861-63 (1951)

61. Cooley, R. A. The genera Dermacentor and Otocenter in the United States, with studies in variation. Natl. Inst. Health Bull., 171, 89 pp. (1938)

62. Cooley, R. A. The genera Boophilus, Rhipicephalus, and Haemaphysalis of the New World. Natl. Inst. Health Bull., 187, 54 pp. (1946)

63. Cooley, R. A., and Kohls, G. M. The genus Amblyomma in the United States. J. Parasitol, 30, 77-111 (1944)

64. Craddock, $\Lambda$. L. Tick typhus in East $\Lambda$ frica. E. African Med. $J$., 36, 579-84 (1959)

65. Cradlock, A. L. Some features of the epidemiology of tick typhus in Kenya. E. African Med. J., 38, 227-31 (1961)

66. Danilevskii, A. S. Photoperiodism and Seasonal Development of Insects. (Oliver and Boyd, Edinburgh and London, 283 pp., 1965)

67. Dias, E., and Vianna Martins, A. Spotted fever in Brazil. A summary. Am. J. Trop. Med., 19, 103-8 (1939)

68. Dick, G. W. A., and Lewis, E. A. A rickettsial disease in East Africa transmitted by ticks (Rhipicephalus simus and Haemaphysalis leachii). Trans. Roy. Soc. Trop. Med. Hyg., 41, 295-326 (1947)

69. Dunn, L. H. The ticks of Panama, their hosts, and the diseases they transmit. Am. J. Trop. Med., 3, 91-104 (1923)

70. Eddy, G. E. Notes on the seasonal history of the rabbit tick, Haema- 
physalis leporispalustris, in Oklahoma. Proc. Entomol. Soc. Wash., 44, 145-49 (1942)

71. Eklund, C. M., Stoenner, H. G., and Kohls, G. M. Rocky Mountain spotted fever. In Practice of Medicine 4, 433-45. (Tice, F., Ed., W. F. Prior Co., Inc., Hagerstown, Md., 755 pp., 1962)

72. Elisberg, B. L., and Bozeman, F. M. (Personal communication, 1966)

73. Elizondo Langagne, A. Fiebre manchada (Spotted fever). Bol. Serv. Hig. Rural Med. Social Comarca Lagunera, 1, 53-68 (19،17)

74. El-Zawahry, M., Abou-Gareeb, A. H., Abd-El-Messih, G., and Imam, I. Z. A serological picture of typhus among a nomadic group in the Western Desert, U.A.R. J. Egypt. Public Health Assoc., 39, 125-34 (1964)

75. Fenner, F. The epidemiology of North Queensland tick typhus: natural mammalian hosts. Med. J. Australia, 2, 666-68 (1946)

76. Fenner, F., and Ratcliffe, F. N. Myxomatosis, (Cambridge Univ. Press, London 379 pp., 1965)

77. Findlay, G. M., and Archer, G. T. L. The occurrence of tick-borne typhus in West Africa. Trans. Roy. Soc. Trop. Med. Hyg., 41, 815-18 (1948)

78. Finlayson, M. H., Grobler, J. M., and Smithers, R. Studies in South African rickettsiosis. S. African J. Med. Sci., 5, 41-45 (1940)

79. Finnegan, S. Acari as agents transmitting typhus in India, Australasia and the Far East. Brit. Museum Nat. Hist., Econ. Ser., 16, 1-78 (1945)

80. Floch, H., and Fauran, P. Ixodides de la Guyane et des Antilles Francaises. Arck. Inst. Pasteur Guyane, 19, 5-94 (1958)

81. Fuller, H. S. Biologic properties of pathogenic rickettsiae. Arch. Inst. Pasteur Tunis, 36, 311-38 (1959)

82. Gastfriend, A. New host records for the immature stages of the tick Dermacentor paramapertas. J. Parasitol., 41, 63-65 (1955)

83. Gear, J. Complication in tick-bite fever. A survey of fifty cases. $S$. African Med. J., 13, 35-36 (1939)

84. Gear, J. The rickettsial diseases of Southern Africa. S. African J. Clin. Sci., 5, 158-75 (1954)

85. Gear, J., and de Mcillon, B. The common dog tick Haemaphysalis leachi as a vector of tick typhus.
S. African Med., J., 13, 815-16 (1939)

86. Gear, J., and de Meillon, B. The hereditary transmission of the rickettsiae of tick-bite fever through the common dog-tick, Haemaphysalis leachi. S. African Med. J., 15, 389-92 (1941)

87. Gear, J. H. S., and Bevan, C. An outbreak of tick-bite fever. $S$. African Med. $J$., 10, 485-88 (1936)

88. Gear, J. H. S., and Douthwaite, M. The dog tick Haemaphysalis leachi as a vector of tick typhus. $S$. African Med. J., 12, 53-55 (1938)

89. George, J. E. Responses of Haemaphysalis leporispalustris to light. In Advances in Acarology, I, 425-30. (Naegele, J. A., Ed., Cornell Univ. Press, Ithaca, N. Y., 480 pp., 1963)

9i). George, I. E. The circadian rhythm of drop-off of engorged Haemaphysalis leporispalustris from rabbits. A carologia, 6 (fasc. h. s.), 343-49 (1964)

91. Giroud, P., Capponi, M., Dumas, N., and Colas-Belcour, J. De la fièvre boutonneuse méditerranéenne au groupe boutonneux pourpré. Bull. Soc. Pathol. Exotique, 56, 629-38 (1963)

92. Giroud, P., Capponi, M., Dumas, N., and Rageau, J. Épidémiologie rurale. Lex Ixodes ricinus et hexagonus de France contiennent des agents rickettsiens ou proches. Compt. Rend., 260, 4874-76 (1965A)

93. Giroud, P., Capponi, M., Dumas, N. and Rageau, J. Épidémiologie rurale. Résultats concernant Dermacentor marginatus et reticulatus préléves dans différentes régions de France et leur contamination avec des éléments proches. Compt. Rend., 260, 5419-21 (1965B)

94. Gould, D. J., and Miesse, M. L. Recovery of a rickettsia of the spotted fever group from Microtus pennsylvanicus from Virginia. Proc. Soc. Exptl. Biol. Med., 85, 558-61 (1954)

95. Grebenyuk, R. V. Ixodid ticks of Issyk-Kul Oblast in Kirgiz SSR. (In Russian). Tr. Zool. Parasitol. Inst. Akad. Nauk Kirgiz SSR, 4, 79-87 (1955); (In English: NAMRU3-T126)

96. Grebenyuk, R. V. Vertical and static distribution of ixodid ticks in Kirgizia. (In Russian). Prirodn. Ochag. Bolez. Vopr. Parasitol., Akad. Nauk Kazakh SSR, 3, 477- 
83 (1961); (In English-NAMRU3T193)

97. Green, R. G., Evans, C. A., and Larson, C. L. A ten-year population study of the rabbit tick Haemaphysalis leporispalustris. Am. J. Hyg., 38, 260-81 (1943)

98. Gregson, J. D. The Ixodoidea of Canada. Can. Dept. Agr. Publ. 930, 92 pp. (1956)

99. Gregson, J. D. Ticks of medical importance in British Columbia. Brit. Columbia Med. J., 2, 1-4 (1960)

100. Grokhovskaya, I. M., Sidorov, V. E., and Korshunova, O. S. Does feeding ticks on immune animals influence Rickettsia sibirica? (In Russian). Med. Parazitol., Moscow, 33, 178-81 (1964); (In English: NAMRU3T204)

101. Harrell, G. T. Rocky Mountain spotted fever. Medicine, Baltimore, 28, 333 (1949)

102. Harrell, G. T. Treatment of Rocky Mountain spotted fever with antibiotics. Ann. N. Y. Acad. Sci., 55, 1027-42 (1952)

103. Harrell, G. T. Physiologic alternations in patients with spotted fever. Med. Sci. Publ., Walter Reed Army Inst. Res., Wash., 7, 23-38 (1960)

104. Heisch, R. B. Rickettsiae from ticks and rodents in Kenya. Trans. Roy. Soc. Trop. Med. Hyg., 51, 287 (1957)

105. Heisch, R. B. The isolation of Rickettsia burneti from Lemniscomys sp. in Kenya. E. African Med. J., 37, 104 (1960)

106. Heisch, R. B. Rodents as reservoirs of arthropod-borne diseases in Kenya. E. African Med. J., 38, 256-61 (1961)

107. Heisch, R. B., and Harvey, A. E. C. Rickettsioses in Kenya: serological reactions of wild rodents and inoculated guinea pigs. E. African Med. $J ., 36,116-18$ (1959)

108. Heisch, R. B., McPhee, R., and Rickman, L. R. The epidemiology of tick-typhus in Nairobi. E. African Med. J. 34, 459-77 (1957)

109. Heisch, R. B., Grainger, W. E., Harvey, A. E. C., and Lister, G. Feral aspects of rickettsial infections in Kenya. Trans. Roy. Soc. Trop. Med. Hyg., 56, 272-86 (1962)

110. Herrin, C. S., and Beck, D. E. Observations on the biology, anatomy, and morphology of Otobius logophilus Cooley and Kohls. Brigham
Young Univ. Sci. Bull., s. Biol., 6, 1-19 (1965)

111. Hoffmann, A. Monografia de los Ixodoidea de Mexico. I. Rev. Soc. Mex. Hist. Nat., 23, 191-307 (1962)

112. Hoogstraal, H. African Ixodoidea. I. Ticks of the Sudan (with special reference to Equatoria Province and with preliminary reviews of the genera Boophilus, Margaropus, and Hyalomma). (U. S. Navy, Washington, D. C., 1101 p., 1956)

113. Hoogstraal, H. Ticks in relation to human diseases caused by viruses. Ann. Rev. Entomol., 11, 261-308 (1966)

114. Hoogstraal, H., Kaiser, M. N., Ormsbee, R. A., Osborn, D. J., Helmy, I., and Gager, S. Hyalomma, (Hyalommina) rhipicephaloides Neumann: its identity, hosts, and ecology, and Rickettsia conori, $\boldsymbol{R}$. prowazeki, and Coxiella burneti infections in rodent hosts in Egypt. J. Med. Entomol. (In press)

115. Hoogstraal, H., Trapido, H., and Kohls, G. M. Southeast Asian Haemaphysalis ticks H. (Kaiseriana) papuana nadchatrami ssp. $\mathrm{n}$. and redescription of $H$. (K.) semermis Neumann. J. Parasitol., 51, 433-51 (1965)

116. Hoogstraal, H., Traylor, M.A., Gaber, S., Malakatis, G., Guindy, E. and Hclmy, $\mathrm{I}$. Ticks on migrating birds in Egypt, spring and fall 1962. Bull. World Health Organ., 30, 355-67 (1964)

117. Hopla, C. E. Observations of the life history of a rabbit tick (Otobius lagophilus). J. Kansas Entomol. Soc., 28, 114-16 (1955)

118. Howell, D. E. The ecology of Dermacentor albipictus (Packard). Proc. Pac. Sci. Congr. Berkeley, Stanford and San Francisco, 6th, 1939, 4, 439-58 (1940)

119. Imam, I. Z. E., and Labib, A. Complement-fixing antibodies against epidemic and murine typhus in domestic animals in U.A.R. $J$. Egypt. Public Health Assoc., 38, 101-9 (1963)

120. Imam, I. Z. E., Safty, A., Omran, F. M., Alfy, L., El Rai, F. M., and Hosny, A. Association between man and domestic animals in typhus infection in Egypt. $J$. Egypt. Public Health Assoc., 40, 47-53 (1965)

121. Janssens, P. G. Problems of the acute 
fever pathology in the tropics. Trop. \&o Geograph. Med. Amsterdam, 15, 337-47 (1963)

122. Jorgensen, C. D. Oviposition habits of the tick Dermacentor parumapertus Neumann and factors influencing egg development. Great Basin Nat., 17, 42-51 (1957)

123. Joyce, C. R., and Eddy G. W. Host and seasonal notes on the rabbit tick, Haemaphysalis leporispalustris. Iowa State Coll. J. Sci. 17, 205-12 (1943)

124. Kaiser, M. N., and Hoogstraal, $H$. The Hyalomma ticks of Pakistan, India, and Ceylon, with keys to subgencra and species. Acarologia, 6, 257-86 (1964)

125. Kalra, S. L. Progress in the knowledge of rickettsial diseases in India. Indian J. Med. Res., 47, 477-83 (1959)

126. Kalra, S. L., and Rao, K. N. A. Typhus group of fevers in Jubbulpore area. Indian J. Med. Res., 37, 373-84 (1949)

127. Kesarev, I. P., and Prodan, Z. G. Experiments on parenteral infection of argasid ticks Ornithodorus papillipes by Rickettsia prowazeki. (In Russian). Probl. Parazitol., Kiev, 2, 61-63 (1063); (In English: NAMRU3-T178)

128. Knight, K. L., and Bryan, D. E. Induced removal of embedded $A m$ blyomma americanum (L.) ticks. Yowa State Coll. J. Sci., 37, 399-416 (1963)

129. Knight, K. L., Bryan, D. E., and Taylor, C. W. Studies on the removal of embedded lone star ticks, Amblyomma americanum. J. Econ. Entomol., 55, 273-76 (1962)

130. Knyvett, A. F., and Sandars, D. F. North Queensland tick typhus: a case report defining a new endemic area. Med. J. Ausiralia, 2, 592-93 (1964)

131. Kohls, G. M. Vectors of rickettsial diseases. In Rickettsial Diseases of Man, 83-96. (Moulton, F. R., Ed., Am. Assoc. for Advan. Sci., Washington, 247 pp., 1948)

132. Kohls, G. M. Records and new synonymy of New World Haemaphysalis ticks, with descriptions of the nymph and larva of $H$. juxlakochi Cooley. J. Parasitol., 46, 355-61 (1960)

133. Kohls, G. M. Book review. Ticks. A monograph of the Ixodiodea. Part V. On the genera Dermacentor, Anocen- tor, Cosmiomma, Boophilus, and Margaropus. (By Arthur, D. R., Cambridge Univ. Press, 251 pp., 1960). Ann. Entomol. Soc. Am., 53, 855-56 (1960)

134. Kohls, G. M., Sonenshine, D. E., and Clifford, C. M. The systematics of the subfamily Ornithodorinae. II. Identification of the larvae of the Western Hemisphere and descriptions of three new species. $A n n$. Entomol. Soc. Am., 58, 331-64 (1965)

135. Kordová, N., and Řehácĕk, J. Experimental infection of ticks in vivo and their organs in vitro with filterable particles of Coxiella burneti. Acta Virol,. Prague. (Engl. ed.), 3, 201-9 (1959)

135. Kordová, N., and Rehácĕk, J. Cultivation of ultrafilterable particles of Coxiella burneti in the tick organism. Folia Microbiol., 4, 275-79 (1959)

13i'. Kordová, N., and Řehácĕk, J. Microscopic examination of the organs of ticks infected with Rickettsia prowazeki. Acta Virol., Prague. (Engl. ed.), 8, 465-69 (1964)

138. Kordová, N., and Řehácĕk, J. Development of Coxiella burneti from their ultrafilterable particles in ticks in vivo, their organs in vitro and in tick tissue cultures. Proc. Intern. Congr. Entomol., 12th, London, 1964, 777 (1965)

140. Korshunova, O. S., and Arkhina, E. V. Study of natural foci of tickborne spotted ty phus. (In Russian). Epidemiol. Parasitol. Eksped. Iran, 291-298 (1948)

141. Korshunova, O. S., and Nikitina, N. A. (1956). [Quoted by Piontkovskaya \& Korshunova, 1963. See Ref. (232)]

142. Korshunova, O.S., and Nikitina, N. A. (1957). [Quoted by Piontkovskaya \& Korshunova, 1963. See Ref. (232)]

143. Korshunova, O. S., Piontkovskaya, S. $P_{\text {, }}$ and Flint, V. E. On natural nidi of tick-borne typhus in Buryat ASSR. (In Russian; Engl. sum.). Zool. Zh., 44, 980-85 (1965)

144. Korshunova, O. S., Piontkovskaya, S. P., and Nikitina, N. A. On natural nidi of Asian tick-borne spotted fever in Khakassia and in the central part of the western Sayan mountains. (In Russian; Engl. sum.). Zool. Zh., 38, 385-93 (1959) 
145. Kotsinyan, M. E. The discovery of the pathogen of a rickettsial disease belonging to the tick-borne spotted fever group in Armenia SSR. (In Russian). Sb. Tr. Inst. Epidem. Gigien. Minist. Zdravookh. Armayn. SSR, Erevan, 2, 117-20 (1956)

146. Kotsinyan, M. E. Endemic rickettsioses in the Armenian SSR. (In Russian). 10. Sovesinch. Parasitol. Probl., Moscow, 1, 87-8 (1959); (In English:JPRS No. 11220, p. 106)

147. Krieg, A. Rickettsiae and Rickettsioses. In Insect Pathology, 1, Chap. 17, 577-617. (Steinhaus, E. A., Ed., Academic Press, New York and London, 661, pp., 1963)

148. Krontovskaya, M. K. (1938). [Quoted by Piontkovskaya \& Korshunova, 1963. See Ref. (232).]

149. Kuang-Leih, J., Chin-Juei, L., YingNan, Y., Ling-Yi C. P. K., and En-Shu, Y. The discovery of natural infection of ticks Ixodes sp. with Rickettsia tsutusgamushi. Chinese Med. J., 78, 276 (1959) Abstr.)

150. Kulagin, S. M., and Kudelina, R. I. An experimental study of the causative agent of Rocky Mountain spotted fever. (In Russian; Engl. sum.). J. Microbiol., Epidemi-l., Immunobiol., USSR, 40, 92-96 (1963)

151. Kulagin, S. M., Tarasevich, I. V., Rubakin, P. E., Nikitin, A. M., and Krupina, $Z$. N. The eradication of Marseilles fever. Some observations on Marseilles fever in Sevastopol. (In Russian). J. Microbiol., Epidemiol., Immunobiol., USSSR, 31, 117-21 (1960); [In Enrlish: $J$. Microbial., London, 31, 1526-31 (1961)]

152. Kulagin S. M., Somov, G. P., Silich, V. A., Fedorova, N. I., Shapir $\bullet$, M. I., Suvorova, L. V., and Bobrovskii, V. N. Further observations on tick-borne rickettsiosis in the Maritime Territory. (In Russian; Engl. sum.). J. Microbiol., Epidemiol., Immunobiol., U.S.SR, 31, 64-71 (1960); [In English: J. Microbiol., London, 31, 1652-60 (1961)]

153. Kuseltan, I. V. On the penetration of adult ticks Hyalomma asiaticum into the skin of lambs. (In Russian; Engl. sum.). Zool. Zh., 43, 138-39 (1964); (In English:NAMRU3T114)

154. Lackman, D. B., and Parker, R, R. The serological characterization of
North Queensland tick typlius. Public Health Rept., US., 63, 162428 (1948)

155. Lackman, D. B., and Pickens, E. G. Antigenic types in the Rocky Mountain spotted fever group of rickettsiae. Bacteriol. Proc., 3, 219 (1953)

156. Lackman, D. B., Parker, R. R., and Gerloff, R. K. Serological characteristics of a pathogenic rickettsia occurring in Amblyomma maculatum. Public Health Rept., U. S., 64, 1342-49 (1949)

157. Lackman, D. B., Bell, E. J., Stoenner, H. G., and Pickens, E. G. The Rocky Mountain spotted fever group of rickettsias. Health Lab. Sci., 2, 135-41 (1965)

158. Lahille, F. Contribution a l'étude des Ixodidés de la République Argentine. An. Ministerio Agr., Secc. Zootec. Bacteriol. Vet. Zool., Buenos Aires, 2, 166 pp., (1905)

159. Lamontellerie, M. Les ixodoüdes $d u$ sud-ouest de la France. Espèces rencontrées, agressivitê, role pathogène. (Imprimerie $\mathrm{E}$. Drouillard, Bordeaux, 145 pp., 1954)

160. Legkodimova, K. V., and Somov, G. P. Data on the clinical aspects, aetiology and epidemiology of tickborne typhus in the Kalinin District of the Primorsk Region. (In Russian; Engl. sum.). J. Microbiol., Epidemiol., Immunobiol., USSR, 32, 112-17 (1961); (In English: $J$. Microbiol., London, 32, 1905-11 1961)

161. Ley, H. L., Jr., and Smadel, J. E. Antibiotic therany of rickettsial diseases. Antibiot. Chemotherapy, 4, 792-802 (1954)

162. Lillie, R. D. The pathology of Rocky Mountain spotted fever. Nall. Insl. Health Bull., 177,59 pp. (1941)

163. Lyskovtsev, M. M. Tick-borne Rickettsiosis (In Russian) (State Publ. House of Medical Literature, Moscovv (MEDGIZ), 275 pp. 196.3); (In English: NAMRU3-T210)

164. Mačička, O., Nosek, J., and Rosický, B. Observations on the bionomics, life-cycle, and economic importance of the tick Dermacentor pictus Herm. in Central Europe. (In Czech., Rus. and Ger. sum.). Biol. Prace, 2, 5-49 (1956)

165. Mačička, O., Rosický, B., and Černý, $V$. Observations on the bionomics and life cycle as well as on the sanitary and economic importance of 
the tick Dermacentor marginatus Sulz. in Central Europe. (In Czech.; Rus. and Ger. sum.). Prace II. Sek. Slovensk. Akad. Vied, s. Biol., 1, 1-43 (1955)

166. Magalhães, O., de. Contribucicão ao conhecimento das doenças de groupo tifo exantematico. Monograph. Inst. Oswaldo Cruz, 6, 968 pp. (1952)

167. Marchette, N. J. Rickettsioses (tick typhus, $Q$ fever, urban typhus) in Malaya. J. Med. Entomol., 2, 33971 (1966)

168. Mason, J. H., and Alexander, R. A. Studies of the rickettsias of the typhus-Rocky-Mountain-spotted fever group in South Africa. III. The disease in the experimental animal. Cross-immunity tests. Onderstepoort J. Vet Sci. Animal Ind., 1.3, 4 1-65 (1939)

169. Mason, J. H., and Alexander, R, A. Studies of the rickettsias of the typhus-Rocky-Mountain-spotted-fever group in South Africa. IV. Discussion and classification. Onderstepoort J. Vet. Sci. Animal Ind., 13, 67-76 (1939)

170. McCroan, J. E., Ramsey, R. L., Murphy, W. J., and Dick, L. S. The status of Rocky Mountain spotted fever in the southeastern United States. Public Health Rept., $U$. S., 70, 319-25 (1955)

171. Megaw, J. W. D. In Trop. Diseases Bull., 51, 910-11 (1954) [See Ref. (58).]

172. Megaw, J. W. D. In Trop. Diseases Bull., 52, 894 (1955) [See Ref. (57).]

173. Mcrinov, V.A. Investigation of North Asian (Siberian) rickettsiosis in Dermacentor nuttalli ticks collected in one of the Krasnoyarsk region foci. (In Russian; Engl. sum.). Med. Parazitol., Moscow, 32, 54-61 (1963); (In English: NAMRU3T155)

174. Merinov, V. A. Ecology of Dermacentor nuttalli and its significance in the epizootology of North Asian rickettsiosis. (In Fussian; Engl. sum.). Probl. Med. Parasitol. Prevent. Infect. Diseases, Moscow, 62143 pp. (1964)

175. Miura, $T$. The life history of the rabbit tick, Haemaphysalis leporispalustris, in the laboratory (In press)

176. Mohr, C. O. The relation of rabbit tick populations to spacing in host populations. J. Parasitol., 47, 605-7 (1961)
177. Mohr, C. O, and Lord, R. D., Jr. Relation of ectoparasite populations to rabbit populations in northern Illinois. J. Wildlife Management, 24, 290-97 (1960)

178. Mooser, H., Imam, I. Z. E., Abbas, M., Morcos, E. G. and Abbass, M. Une enquête sêrologique sur le typhus en Egypte. Bull. Soc. Pathol. Exotique, 56, 586-89 (1963)

179. Neilson, G. H. A case of Queensland tick typhus. Med. J. Australia, 1, 763-64 (1955)

180. Neitz, W. O., Alexander, R. A. and Mason, $J$. H. The transmission of tick-bite fever by the dog tick Rhipicephalus sanguineus, Latr. Onderstepoort J. Vet. Sci. Animal Ind., 16, 9-17 (1941)

181. Netsky, G. I., and Shaiman, M. S. Distribution and relationships between foci of tick-borne encephalitis, tick typhus of northern Asia, and $Q$ fever in western Siberia. (In Russian; Engl. sum.). Med. Parazitol., Moscow, 33, 136-41 (1964); (In English: NAMRU 3-T159)

182. Newhouse, V. F., McKiel, J. A., and Burgdorfer, W. California encephalitis, Colorado tick fever and Rocky Mountain spotted fever in eastern Canada. Can. J. Public Health, 55, 257-61 (1964)

133. Nguyen-Van-Ai. Á propos de 114 diagnostics serologiques par microagglutination des rickettsies sur lame pratiques à Saigon en 1962 . Rapp. Ann. sur le Foncl. Tech., Saigon, 35-38, (1962)

184. Olsuf jev, N. G. On the paleogenesis of the causative agent of tularemia. In Theoretical Questions of Natural Foci of Diseases, Proceedings of a Symposium, Prague, November 26-29, 1963, 369-78. (Rosický, B., and Heyberger, K., Eds., Czechoslovak Acad. Sci., 530 pp. 1965)

185. Ormsbee, R. A. (Personal communication, 1966)

186. Ortiz Mariotte, C., and Varela, G. Cultivo del Rhipicephalus sanguineus en el laboratorio y vacuna hecha conesta garrapata. Med. Rev. Mexico, 29, 323-35 (1949)

187. Ortiz Mariotte, C., Bustamante, $M$. E., and Varela, G. Hallazgo del Rhipicephalus sanguineus infectado naturalmente con fiebre manchada de las Montanas Rocosas en Sonora (México). Rev. Inst. Salubridad Enfermedades Trop. Mex., 5, 297-300 (1944) 
188. Pakshin, M. F., Pestenko, V. I., and Kostetskii, N. V. The epidemiology of Marseilles fever in the Crimea and ways of eradicating the disease. (In Russian; Engl. sum.). J. Microbiol., Epidimiol., Immunopathol., U.S.S.R., 31, 61-64 (1960); (In English: J. Microbiol., London, 31, 1648-51, 1961)

189. Parker, R. R. Transmission of the Rocky Mountain spotted fever by the rabbit tick Haemaphysalis leporispalustris Packard. Am. J. Trop. Med., 3, 39-45 (1923)

190. Parker, R. R. A pathogenic rickettsia from the gulf coast tick, Amblyomma maculatum. Proc. Intern. Congr. Microbiol., 3rd, 390-91 (1940)

191. Parker, R. R. Ornithodoros ticks as a medium for the transportation of disease agents. Public Health Rept. U. S., 57, 1963-66 (1942)

192. Parker, R. R., and Oliphant, J. W. Rocky Mountain spotted fever. In Communicable Diseases, Chap. 46c, 719-52. (Lea \& Febiger, Philadelphia, Pa., 1035 pp., 1950)

193. Parker. R. R., Kohls, G. M. and Steinhaus, E. A. Rocky Mountain spotted fever: Spontaneous infection in the tick Amblyomma americanum. Public Health Rept. U. S., 58, 721-29 (1943)

194. Parker, R. R., Kohls, G. M., Cox, G. W., and Davis? G. E. Observations on an infectious agent from $\mathrm{Am}$ blyomma maculatum. Public Health Rept., U. S., 54, 1482-84 (1939)

195. Parker, R. R., Bell, J. F., Chalgren, W. S., Thrailkill, F. B., and McKee, M. T. The recovery of strains of Rocky Mountain spotted fever and tularemia from ticks of the eastern United States. J. Infect. Diseases, 91, 231-37 (1952)

197. Patiño-Camargo, L. Nuevas observaciones sobre un tercer foco de fiebre petcquial (maculosa) en el hemisferio americano. Bol. Ofic. Sanit. Panam., 20, 1112-24 (1941)

198. Patiño, L., Afanador, A., and Paul, J. H. A spotted fever in Tobia, Colombia. Am. J. Trop. Med., 17, 639-53 (1937)

199. Pavlov, P. The theory of E. N. Pavlovsky on the natural focal occurrence of diseases and the development of this theory in Bulgaria. (In Russian). J. Microbiol., Epidemiol., Immunobiol,. U.S.S.R., 31, 80-84 (1960); (In English; $J$.
Microbiol., London., 31, 1673-78, 1961)

200. Pavlov, P., and Popov, A. Presence de la tique Amblyomma hebraeum (Koch 1844) en Bulgarie. (In Bulgarian; Russ, and Fr. sum.). Izv. Inst. Eksp. Vet. Med., Bulgar. Akad. Nauk., 1, 211-16 (1951)

201. Payzin, S. Rickettsial infections in Turkey in the past and present. Proc. Intern. Congr. Trop. Med. Malaria, oth, Lisbon, 1958, 5, 776-83 (1959)

202. Payzin, S., and Akan, E. Residual agglutinins against $R$. prowazekii, $R$. mooseri, $R$. conori, $R$. burnetii and neo-rickettsia in human sera from central and eastern Turkey. (In Turkish and English). Turk Ijiyer Tecrubi Biyol. Dergisi, 24, 44--62 (1964)

203. Petrischeva, P. A. Epidemic importance of territories situated in adjoining landscapes. (In Russian). Prirod. Ochagovost Boleznei Chelovek. Kraev, Epidemiol., 36-49 (1955)

204. Philip, C. B. Nomenclature of the rickettsiaceae pathogenic to vertebrates. Ann. N. Y. Acad. Sci., 56, 484-94 (1953)

205. Philip, C. B. Comments on the classification of the order Rickettsiales. Can. J. Microbiol., 2, 261-70 (1956)

206. Philip, C. B. Some epidemiological considerations in Rocky Mountain spotted fever. Public Health Rept., U.S., 74, 595-600 (1959)

207. Philip, C. B. Book review. Ticks. A monograph of the Ixodoidea. Part V. On the genera Dermacentor, Anocentor, Cosmiomma, Boophilus, and Margaropus. (By Arthur, D. R., Cambridge Univ. Press, 251 pp., 1960). Science, 132, 291 (1960)

208. Philip, C. P. Recent advances in knowledge of tick-associated rickettsia-like organisms. J. Egypt. Public Health Assoc., 38, 61-100 (1963)

209. Philip, C. B. Ticks as purveyors of animal ailments: A review of pertinent data and of recent contributions. In Advances in Acarology, I, 285-325 (Naegele, J. A., Ed., Cornell Univ. Press, Ithaca, N. Y., 480 pp., 1963)

210. Philip, C. B. (Personal communication, 1966)

211. Philip, C. B., and Burgdorfer, W. Arthropod vectors as reservoirs of microbial disease agents. Ann. Rev. Entomol., 6, 391-412 (1961)

212. Philip, C. B., and Hughes, L. E. Dis- 
ease agents found in the rabbit tick Dermacentor parumapertus, in the southwestern U. S. (abstr.). Sixth Intern. Congr. Microbiol., 6th Rome, $1953,2,600$ (1953)

213. Philip, C. B., and Kohls, G. M. Elk, winter ticks, and Rocky Mountain spotted fever: A query. Public Health Rept. U. S., 66, 1672-75 (1952)

214. Philip, C. B., and Parker, R. R. Rocky Mountain spotted fever. Investigation of sexual transmission in the wood tick Dermacentor andersoni. Public Health Rept., U. S., 48, 26672 (1933)

215. Philip, C. B., and White, J. S. Disease agents recovered incidental to a tick survey of the Mississippi Gulf Coast. J. Econ. Entomol., 48, 396400 (1955)

216. Philip, C. B., Bell, J. F., and Larson, C. L. Evidence of infectious diseases and parasites in a peak population of black-tailed jack rabbits in Nevada. J. Wildlife Management, 19, 225-33 (1955)

217. Philip, C. B., Gill, G. D., and Geary, J. M. Notes on the rabbit tick, Haemaphysalis leporispalustris (Packard), and tularemia in central Alaska. J. Parasitol., 40, 484-85 (1954)

218. Philip, C. B., Hoogstraal, H., Reiss Gutfreund, R. J., and Clifford, C. $M$. Evidence of disease agents in ticks from Ethiopian cattle. Bull. World Health Organ. (In press, 1966)

219. Philip, C. B. Hughes, L. E., Rao, K. N. A., and Kalra, S. L. Studies on Indian tick typhus and its relation to other human, typhuslike rickettsioses. Intern. Congr. Microbiol., 5th, Rio de Janeiro, 1950, 1, 571-74 (1958)

220. Pickens, E. G., Bell, E. J., Lackman, D. B., and Burgdorfer, W. Use of mouse serum in identification and serologic classification of Rickettsia akari and Rickettsia australis. J. Immunol., 94, 883-89 (1965)

221. Pijper, A. Tick-bite fever. A clinical lecture. S. African Med. J., 8, 55156 (1934)

222. Pijper, A. Étude expórimentale comparée de la fièvre boutonneuse et de la tick-bite-fever. Arch. Inst. Pasteur Tunis, 25, 388-401 (1936)

223. Pijper, A., and Crocker, C. G. Rickettsioses of South Africa. S. African Med. J., 12, 613-30 (1938)
224. Pijper, A., and Dau, H. The aetiology of tick-bite fever. J. Trop. Med. Hyg., 33, 93-94 (1930)

2.25. Pijper, A., and Dau, H. The transmissibility of tick-bite fever virus to guinea-pigs. Brit. J. Exptl. Pathol., 11, 287-90 (1930)

226. Pijper, A., and Dau, H. Die fleckfieberartigen Krankheiten des siidlichen Afrika. Zentr. Bakteriol. Parasilenk., Abt. I, Orig., 133, 7-22 (1934)

227. Pijper, A., and Dau, H. South African typhus. J. Hyg., 35, 116-24 (1935)

228. Piontkovskaya, S. P. (1957). [Quoted byLyskovtsev, 1963. See Ref. (163).]

229. Piontkovskaya, S. P. (1959). [Quoted by Lyskovtsev, 1963. See Ref. (163.)]

230. Piontkovskaya, S. P., and Flint, V.E. On the ecology of immature forms of Dermacentor nutialli Olen. and of other ticks of wild rodents in Ubsunur hollow of Tuva ASSR. (In Russian; Engl. sum.). Zool. Zh., 43, 178-84 (1964)

231. Piontkovskaya, S. P., and Korshunova, O. S. Experiments in infection of Dermacentor marginatus Sulz. and Dermacentor pictus Herm. ticks with Rickettsia prowaseki. (In Russian). Vopr. Kraj. Obshchestovo Eksp. Parazitol., 8, 29-33 (1953)

232. Piontkovskaya, S. P., and Korshunova, O. S. Asian tick typhus. In Human Diseases with Natural Foci, 98-137. (Pavlovksy, Y. N., Ed., Foreign Languages Publ. House, Moscow, 355 pp., 1963)

233. Piontkovskaya, S. P., and Mischenko, N. K. Ecology of Dermacentor nuttalli Olen. and of some other ectoparasites of rodents in a natural reservoir of tick-borne typhus fever in the Tuva Autonomous Region. (In Russian; Engl. sum.). Med. Parazitol., Moscow, 28, 164-70 (1959)

234. Piontkovskaya, S. P., Belayeva, A. P., and Korshunova, O. S. (1939). [Quoted by Lyskovtsev, 1963. See Ref. (163).]

235. Piontkovskaya, S. P., Flint, V. E., and Korshunova, O. S. Natural nidality of tick-borne exanthematous fever in Ubsunursk basin of Tuva A. O., RSFSR. (In Russian). Med. Parazitol., Moscow, 32, 58185 (1963)

236. Pomerantzev, B. I. Ixodiclae. (In Russian). Fauna of the U.S.S.R., 4, 224 pp. (1950); (In English: Inst. of 
Acarology, Dept. of Zool., Univ. of Maryland, College Park)

237. Pope, J, H. The isolation of a rickettsia resembling Rickettsia australis in southeast Queensland. Med. J. Australia, 1, 761-63 (1955)

238. Popov. V. M. Ixodid ticks of northern Siberia and diseases with natural focality, 25-31. In Natural Focal Diseases (Moscow) (1958)

239. Portman, R. W. Winter distribution of two ectoparasites of the cottontail rabbit in Missouri. J. Econ. Entomol., 37, 541 (1944)

240. Pratt, E. P., Drysdale, A. D., and Kirk, R. Typhus fevers in the Anglo-Egyptian Sudan. J. Trop. Med. Hyg., 52, 157-60 (1949)

241. Pratt, H. D., and Littig, K. S. Ticks of public health importance and their control. Training guide. Insect control series. U. S. Publ. Health Serv., Commun. Disease Center, Atlanta. 42 pp. (1961)

242. Preobrazhensky, A. A. Tick typhus in Primorye territory. (In Russian). Med. Parazitol., Moscow, 15, 53-62 (1946)

243. Price, E. G. Fighting spotted fever in the Rockies. (Naegele Printing Co., Helena, Møntana, 269 pp., 1948)

244. Price, W. H. A quantitative analysis of the factors involved in the variations in virulence of rickettsiae. Science, 118, 49-52 (1953)

245. Price, W. H. The epidemiology of Rocky Mountain spotted fever. I. The characterization of strain virulence of Rickettsia rickettsii. Am. J. Hyg., 58, 248-68 (1953)

246. Price, W. H. The epidemiology of Rocky Mountain spotted fever. II. Studies on the biological survival mechanism of Rickettsia rickettsii. Am. J. Hyg., 60, 292-319 (1954)

247. Proreshnaya, T. L., and Rapoport, L. P. Study of natural foci of tick rickettsioses in southwestern Kirgizia. (In Russian). J. Microbiol., Epidemiol., Immunobiol., U.S.S.R., 40, 56-60 (1963); (In English: NAMRU3-T131)

248. Razumova, V. N. Seasonal development of diapause in Dermacentor pictus (Herm.) and factors stimulating it. (In Russian). Med. Parazitol., Moscow, 34, 46-52 (1965)

249. Řeháček, J. Development of animal viruses and rickettsiae in ticks and mites. Ann. Rev. Entomol., 10, 1-24 (1965)

250. Reiss-Gutfreund, R. J. Isolement de souches de Rickettsia prowazeki à partir du sang des animaux dømestiques d'Ethiopie et de leurs tiques. Bull. Soc. Pathol. Exotique, 48, 6027 (1955)

251. Reiss-Gutfreund, R. J. Un nouveau réservoir de virus pour Rickettsia prowazeki: Les animaux domestiques et leurs tiques. Bull. Soc. Pathol. Exotique, 49, 946-1021 (1956)

252. Reiss-Gutfreund, R. J. Nouveaux isolements de $R$. prowazeki à partir d'animaux domestiques et de tiques. Bull. Soc. Pathol. Exotique, 54, 284-97 (1961)

253. Reznik, P. A. Morphology of tick larvae of the genus Dermacentor Koch. (In Russian; Engl. sum.). Zo»l. Zh., 35, 1152-62 (1956)

254. Reznik, P. A. Study of immature stages of ixodid ticks. IV. Morphology of nymphs of Dermacentor Koch. (In Russian; Engl. sum.). Zool. Zh., 38, 1797-1805 (1959)

255. Roberts, F. H. S. A systematic study of the Australian species of the genus Ixodes. Australian J. Zool., 8, 392-485 (1960)

256. Roberts, J. I. The ticks of rodents and their nests, and the discovery that Rhipicephalus sanguineus Latr. is the vector of tropical typhus in Kenya. J. Hyg., 35, 1-22 (1935)

257. Roberts, J. I. Notes on typhus fevers in Kenya. J. Hyg., 39, 345-53 (1939)

258. Roberts, J. I., and Tonking, H. D. A preliminary note on the vector of tropical typhus in Kenya. $E$. African Med. J., 9, 310-15 (19.33)

259. Rodaniche, E. C. de. Natural infection of the tick, Amblyomma cajennense with Rickettsia rickettsii in Panama. Am. J. Trop. Med. Hyg., 2, 696-99 (1953)

260. Rodaniche, E. C. de, and Rodaniche, A. Spotted fever in Panama; isolation of the etiologic agent from a fatal case. $A m$. J. Trop. Med., 30, 511-17 (1950)

261. Ross, I. C. The bionomics of Ixodes holocyclus Neumann, with a redescription of the adult and nymphal stages and a description of the larvae. Parasitology, 16, 365-81 (1924)

262. Sartbaev, S. K. Ticks of the genus Haemaphysalis in Kirgizia. (In Russian). Prirod. Ochagovost Boleznei Vopr. Parasitol., Akad. Nauk 
Kaz. SSR, 4, 484-88 (1961); (In English: NAMRU3-T120)

263. Savitskaya, E. P. (1939). QQuoted by Piontkovskaya \& Korshunova, 1963. See Ref. (232).]

264. Schulze, P. Die heutige Verbreitung enzelner Tierarten im Lichte der exdgeschichtlichen Vergangenheit. (Besonders der Zecken Dermacentor reticulatus Auct. und Hyalomma marginatum Koch). Z. Morphol. Oekol. Tiere., 15, 735-54 (1929)

265. Seddon, H. R. Diseases of domestic animals in Australia. Serv. Publication, Dept. Health, Div. Vet. Sci. (Australia), 7, 200 pp., (1951)

266. Shaiman, N. S. The virological characteristics of the focus of tick epidemic typhus in Novosibirsk Oblast. (In Russian). Tr. Omsk. Nauch.-Issled. Inst. Epidemiol. Mikrobiol. Gig. Omsk., 4, 73-76, (1957)

267. Shepard, C. C., and Goldwasser. R. A. Fluorescent antibody staining as a means of detecting Rocky Mountain spotted fever infection in individual ticks. Am. J. Hyg., 72, 120-29 (1960)

268. Shirai, A., Bozeman, F. M., Perri, S., Humphries, J. W., and Fuller, H. S. Ecology of Rocky Mountain spotted fever. I. Rickettsia rickettsii recovered from a cottontail rabbit from Virginia. Proc. Soc. Exptl. Biol. Med., 107, 211-14 (1961)

269. Shortt, H. E., and D'Silva, H. A. M. The distribution of Indian tick typhus with notes on laboratory findings. Indian Med. Gaz., 71, 1321 (1936)

270. Sigalas, R., and Lamontellerie, $M$. Problèmes posés par l'épidémiologie de la fièvre boutonneuse. J. Med. Bordeaux, 131, 963-68 (1954)

271. Silva-Goytia, R. Vectores y reservorios de la fiebre manchada Americana en Mexico. Intern. Congr. Micro. biol., 6th, Rome, 1953. 6, 603-4 (1953)

272. Silva-Goytia, R., and Elizondo, A. Estudios sobre fiebre manchada en Mexico. Med. Rev. Mexico, 32, 21721 (1952A)

273. Silva-Goytia, R., and Elizondo, A. Estudios sobre fiebre manchada en Mexico. II. Parasitos hematofagos encontrados naturalmente infectados. Med. Rev., Mexico, 32, 27882 (1952B)

274. Silva-Goytia, R., and Elizondo, A. Estudios sobre fiebre manchada en
Mexico. IV. Characteristicas epidemiologicas de casos de fiebre manchada ocurridos en la Laguna. Med. Rev. Mexico, 32, 569-79 (1952C)

275. Smadel, J. E. Status of the rickettsioses in the United States. Ann. Internal Med., 51, 421-35 (1959)

276. Smadel, J. E. Rocky Mountain spotted fever vaccine. Med. Sci. Publ., Walter Reed Army Inst. Res., Wash., 7, 55-61 (1960)

277 . Smadel, J. E. Intracellular infection and the carrier state. Science, 140, 153-60 (1963)

278. Smadel, J. E., and Elisberg, B. L. Scrub typhus rickettsia. In Viral and Rickettsial Infections of Man, Chap. 51, 1130-43. (Horsfall, F. L., Jr., and Tamm, I., Eds., J. B. Lippincott Co., Philadelphia, 1282 pp., 1965)

27!). Smadel, J. E., and Jackson, E. B. Rickettsial infections. In Diagnostic Procedures for Viral and Rickettsial Diseases, 3rd ed., Chap. 29, 743-72. (Lennette, E. H., and Schmidt, N. J., Eds., Am. Public Health Assoc., New York, 814 pp., 1964)

280. Smith, C. N., Cole, M. M., and Gouck, $\mathrm{H}$. K. Biology and control of the American dog tick. U. S. Dept. Agr. Tech. Bull., 905, 74 pp. (1946)

281. Snetsinger, R. J., Witte, E. J., Wills, W. Rocky Mountain spotted fever found annually in Pennsylvania Sci. Farmer, 12, 4-5 (1965)

282. Snyder, J. C. The treatment of the rickettsial diseases of man. In Rickettsial Diseases of Man, 169-77. (Moulton, F. R., Ed., Am. Assoc. Advan. Sci., Washington, 247 pp., 1948)

283. Somov, G. P. and Shestakov, V. I. On spontaneous infection of Haemaphysalis japonica douglasi Nutt. and Warb. ticks with $D$. sibiricus rickettsiae in Primorski Region. (In Russian). J. Microbiol., Epidemiol., Immunobiol., U.S.S.R., 40, 5156 (1963); (In English-NAMRU3T205)

284. Sornov, G. P., and Soldatov, G. M. The role of birds in circulating the causative agent of tick-borne exanthematous typhus (Rickettsial fever occurring in Siberia) in nature. (In Russian). J. Microbiol., Epidemiol., Immunobiol., U.S.S.R., 41, 126-29 (1964)

285. Somov, G. P., Shapiro, M. I., and Petrov, A. A. Study of an island 
focus of northern Asian tick-borne typhus. (In Russian). J. Microbiol., Epidemiol., Immunobiol., U.S.S.R., 29, 94-99 (1958); (In English: $J$. Microbiol., London, 29, 761-66, 1958)

286. Sonenshine, D. E. (Personal communication, 1965)

286a. Sonenshine, D. E., Lamb, J. T., and Anastos, G. The distribution, hosts and seasonal activity of Virginia ticks. Virginia J. Sci., 16, 26-91 (1965)

287. Sonenshine, D. E., Elisberg. B. L., Atwood, E. L., and Lamb, J. T. The ecology of tick vectors of Rocky Mountain spotted fever in Virginia, U.S.A. Proc. Intern. Congr. Parcsitol. 1st, Rome, 1964. (In press)

288. Spencer, F. J. Tick-borne disease in Virginia, 1949-1958. An ecological note. Am. J. Trop. Med. Hyg., 10, 220-22 (1961)

289. Spencer, R. The fleas, the ticks, spotted fever and me. Saturday Rev., Nov. 2, 47-49 (1963)

290. Stannard, L. J., and Pietsch, L. R. Ectoparasites of the cottontail rabbit in Lce County, northern Illinois. Illinois Nat. Hist. Surv., Div. Biol. Notes, 38, 1-19 (1958)

291. Starkoff, O. Ixodoidea D'Italia. Studio Monografico. (Il Pensiero Scientifico, Rome 385 pp., 1958)

292. Steinhaus, E. A. Insect Microbiology, (Vail-Ballou Press, Binghamton, New York, 763 pp., 1947)

293. Strickland, R. K., and Gerrish, R. R. Distribution of the tropical horse tick in the United States, with notes on associated cases of equine piroplasmosis. J. Am. Vet. Med. Assoc., 144, 875-78 (1964)

294. Strickland, R. K., and Gerrish, R. R. Collections of Dermacentor parumapertus from cattle. J. Parasitol., 51, 1000 (1965)

295. Suslov, S. P. Physical Geography of Asiatic Russia. (Williams, J. E., Ed., W. A. Freeman and Co., San Francisco and London, 594 pp., 1961)

296. Teng, K. F. On the biology of the pasture tick, Dermacentor nuttalli Olenev, in Inner Mongolia Autenomous Region, China. (In Chinese; Engl. sum.). Acta Entomol. Sinica, 11, 370-76 (1962)

297. Theiler, G. Zoological survey of the Union of South Africa. Tick survey. 1. Onderstepoort J. Vet. Sci. Animal Ind., 23, 217-31 (1948)
298. Theiler, G. The Ixodoidea parasites of vertebrates in Africa south of the Sahara (Ethiopian region). Rept. Vet. Serv. Onderstepoort, 1, 1-255 (1962) (Mimeographed)

299. Theiler, G., and Robinson, B. N. Ticks in the South African zoological survey collection. Part VII. Six lesser known African rhipicephalids. Onderstepoort J. Vet. Res. Animal Ind., 26, 93-135 (1953)

300. Theiler, G., and Salisbury, L. E. Ticks in the South African zoological survey collection. IX. The $A m$ blyomma marmoreum group. Onderstepoor IJ. Vet. Res. Animal Ind., 28, 47-124 (1959)

301. Tobie, J. E., Burgdorfer, W., and Larson, C. L. Frozen sections of arthropods for histological studies and fluorescent antibody investigations. Exptl. Parasitol., 11, 50-55, (1961)

302. Toledo Piza, J. de, Meyer, J. R., and Salles Gomes, L. Typho exanthematico de Sao Paulo (Sao Paulo, 156 pp., 1932)

303. Topping, N. H. Rocky Mountain spotted fever. A note on some aspects of its epidemiology. Public Health Rept. U. S., 56, 1699-1703 (1941)

304. Topping, N. H. A strain of Rocky Mountain spotted fever virus of low virulence isolated in the western United States. Public Health Rept. U. S., 56, 2041-43 (1941)

305. Troup, J. M., and Pijper, A. Tick-bite fever in southern Africa. Lancet, Nov. 28, 1183-85 (1931)

306. Vinson, J. W. In vitro cultivation of Rickettsia quintana. Proc. Intern. Congr. Trop. Med. Malaria, 7th Rio de Janeiro, 1963, pp. 329-30 (1963) (Abstr.).

307. Voshchakina, N. V. Epidemiological and etiological characteristics of North Asian tick-borne exanthematous typhus in the Armizonskoye District of Tyumen Province. (In Russian; Engl. sum.). J. Microbiol., Epidemiol. Immunobiol., U.S.S.R., 33, 47-53 (1962)

308. Walker, J. B. Rhipicephalus pulchellus Gerstacker 1873: A description of the larva and nymph with notes on the adults and on its biology. Parasitology, 45, 95-98 (1955)

309. Walker, J. B. Some observations on the classification and biology of ticks belonging to the genus Rhipicephalıs, with special reference to 
the immature stages. E. African Med. J., 38, 232-38 (1961)

310. Weyer, F. Vergleichende Untersuchungen ijber das Verhalten verschiedener Fickettsien-Arten in der Kleiderlaus. Z. Tropenmed. Parasitol., 11, 193-221 (1954)

311. Weyer, F. Beoba.chtungen bei der Übertragung von brasilianischem Fleckfieber und sibirischem Zeckenbissfieber auf die Kleiderlaus. $Z$. Tropenmed. Parasitol., 9, 174-93 (1958)

312. Weyer, F. Biological relationships between lice (Anoplura) and microbial agents. Ann. Rev. Entomol., 5, 405-20 (1960)

313. Wilcocks, C. Medical organization and diseases of Burma before the Japanese invasion. Trop. Diseases Bull., 41, 621-30 (1944)

314. Wisseman, C. L. (Personal communication, 1966)

315. Wolbach, S. B. The pathology of the rickettsial diseases of man. In Rickettsial Diseases of Man, 118-25. (Moulton, F. R., Ed., Am. Assoc. Advan. Sci., Washington, D. C., 247 pp., 1948)

316. Woodward, D. B., and Camin, J. H. Host-selection behavior in the rabbit tick, Haemaphysalis leporispalustris. (In press)

317. Woodward, T. E. Clues to better understanding of the nature and treatment of certain infectious diseases. Am. J. Med. Sci., 231, 369-81 (1956)

318. Woodward, T. E. Rickettsial diseases in the United States. Med. Clin. $N$. Am., 43, 1507-35 (1959)

319. Woodward, T. E., and Jackson, E. B. Spotted fever rickettsiae. In Viral and Rickettsial Injections of Man, 4th ed, Chap. 50, 1095-1129 (Horsfall, F. L., Jr., and Tamm, I.,
Eds., J. B. Lippincott Co., Philadelphia, 1282 pp., 1965)

320. Woodward, T. E., and Raby, W. T. Further concepts in the treatment of Rocky Mountain spotted fever with para-aminobenzoic acid. Southern Med. J., 41, 997-1003 (1948)

321. Woodward, T. E., and Smadel, J. E. The Rickettsioses. In Principles of Internal Medicine, Sect. 12, 10901108 4th ed. (Harrison, T. R., Ed., McGraw-Hill, New York, 1947 pp., 1962)

322. Workman, J. B., Hightower, J. A., Borges, F. J., Furman, J. E., and Parker, R. T. Cortisone as an adjunct to chloramphenicol in the treatment of Rocky Mountain spotted fever. New Engl. J. Med., 246, 962-66 (1952)

323. Yashkul, V. K. On the causes of summer inactivity of mature Dermacenlor marginalus Sulz. Ticks (In Russian; Engl. sum.). Zool. Zh., 39, 4552 (1960)

324. Yashkul, V. K. Diapause in Dermacentor marginatus Sulz. ticks and its biological significance. (In Russian). Prirod. Ochagorost Boleznei Vop. Parasitol., Akad. Nauk Kaz., SSR, 4, 498-501 (1961)

325. Zdrodovskii, P. F., and Golinevich, E. M. The Rickettsial Diseases (Engl. ed.) (Pergamon Press, New York, 629 pp., 1960)

326. Zhmaeva, Z. M. Haemaphysalis concinna Koch ticks as vectors of tickborne spotted typhus in the Far East. In Conf. Parasitol. Probl. Maritime, 3rd. (Pavlovsky, E. N., Ed., 1941); (In Russian). Izd. Akad. Nauk SSR, p. 14. Also in Vestn. Sel.-Khoz. Nauk Vet., Moscow, 3, 134-35 (Abstr.). 